This is the peer-reviewed, accepted version of the following article: Radinger, J, Britton, JR, Carlson, SM, et al. (2019) Effective monitoring of freshwater fish. Fish and Fisheries. In press. 1-19, which has been published in final form at https://doi.org/10.1111/faf.12373.

\title{
Effective monitoring of freshwater fish
}

Johannes Radinger ${ }^{*}, 1$, J. Robert Britton ${ }^{2}$, Stephanie M. Carlson ${ }^{3}$, Anne E. Magurran ${ }^{4}$, Juan Diego Alcaraz-Hernández ${ }^{1}$, Ana Almodóvar ${ }^{5}$, Lluís Benejam ${ }^{6}$, Carlos Fernández-Delgado $^{7}$, Graciela G. Nicola ${ }^{8}$, Francisco J. Oliva-Paterna ${ }^{9}$, Mar Torralva ${ }^{9}$, Emili García-Berthou ${ }^{1}$

${ }^{1}$ GRECO, Institute of Aquatic Ecology, University of Girona, 17003 Girona, Spain

${ }^{2}$ Faculty of Science and Technology, Bournemouth University, Fern Barrow, Poole, Dorset, United Kingdom

${ }^{3}$ Department of Environmental Science, Policy, and Management, University of California, Berkeley, CA 94720-3114, USA

${ }^{4}$ Centre for Biological Diversity, School of Biology, University of St Andrews, St Andrews KY16 9TH, United Kingdom

${ }^{5}$ Department of Biodiversity, Ecology and Evolution, Complutense University of Madrid, 28040 Madrid, Spain

${ }^{6}$ Aquatic Ecology Group, University of Vic - Central University of Catalonia, 08500 Vic, Spain

${ }^{7}$ Departamento de Zoología, Facultad de Ciencias, Universidad de Córdoba, 14071 Córdoba, Spain

${ }^{8}$ Department of Environmental Sciences, University of Castilla-La Mancha, 45071 Toledo, Spain

${ }^{9}$ Departamento de Zoología y Antropología Física, Universidad de Murcia, 30100 Murcia, Spain

*corresponding author: johannes.radinger@udg.edu, ORCiD: 0000-0002-2637-9464 


\begin{abstract}
Freshwater ecosystems constitute only a small fraction of the planet's water resources, yet support much of its diversity, with freshwater fish accounting for more species than birds, mammals, amphibians, or reptiles. Fresh waters are, however, particularly vulnerable to anthropogenic impacts, including habitat loss, climate and land use change, pollution, and biological invasions. This environmental degradation, combined with unprecedented rates of biodiversity change, highlights the importance of robust and replicable programmes to monitor freshwater fish. Such monitoring programmes can have diverse aims, including confirming the presence of a single species (e.g. early detection of alien species), tracking changes in the abundance of threatened species, or documenting long-term temporal changes in entire communities. Irrespective of their motivation, monitoring programmes are only fit for purpose if they have clearly articulated aims and collect data that can meet those aims. This review, therefore, highlights the importance of identifying the key aims in monitoring programmes, and outlines the different methods of sampling freshwater fish that can be used to meet these aims. We emphasise that investigators must address issues around sampling design, statistical power, species' detectability, taxonomy, and ethics in their monitoring programmes. Additionally, programmes must ensure that high-quality monitoring data are properly curated and deposited in repositories that will endure. Through fostering improved practice in freshwater fish monitoring, this review aims to help programmes improve understanding of the processes that shape the Earth's freshwater ecosystems, and help protect these systems in face of rapid environmental change.
\end{abstract}

Keywords: Biodiversity Targets; Ecological Monitoring; Environmental Assessment; Environmental Management; Rivers; Sampling Design 


\section{Introduction}

Human-driven environmental changes continue to raise substantial concerns for biodiversity conservation and have led to the development and implementation of many ecological monitoring programmes around the world (Nichols \& Williams, 2006). These programmes generally aim to understand and manage the interactions of environmental change with biodiversity (Fölster et al., 2014). Given the increasing seriousness of environmental degradation, the need for effective ecological and biodiversity monitoring programmes has never been higher (Lindenmayer \& Likens, 2010). Freshwater ecosystems are particularly imperilled by anthropogenic activities worldwide. Although fresh waters cover less than $1 \%$ of the earth's surface, they support high levels of biodiversity (Dudgeon et al., 2006; Strayer \& Dudgeon, 2010). Extinction rates of freshwater taxa are considerably higher than terrestrial species (Sala et al., 2000), due to issues including habitat loss, climate and land use change, pollution, and biological invasions (Ormerod et al., 2010; Stendera et al., 2012). At approximately 13,000 species, freshwater fish represent $40-45 \%$ of global fish diversity (Lévêque et al., 2008), with this highly diverse group including some of the most imperilled animals on the planet (Cooke et al., 2012).

Freshwater fishes also provide ecosystem services of major economic, nutritional, scientific, historical, and cultural importance (IUCN FFSG, 2015). For example, freshwater and marine fisheries jointly constitute the largest extractive use of wildlife in the world and contribute to overall economic wellbeing by means of export commodity trade, tourism, and recreation (Santhanam, 2015). Freshwater fish provide a major source of protein for humans and support the livelihoods of many people (Holmlund \& Hammer, 1999), particularly in the Global South. However, there are serious threats to this valuable resource related to over-exploitation and other anthropogenic stressors (Allan et al., 2005; de Kerckhove et al., 2015).

The wide range of responses of freshwater fishes to anthropogenic stressors make fish valuable indicators for assessing the biological and ecological integrity of fresh waters and their catchments (Fausch et al., 1984; Magurran et al., 2018; Schiemer, 2000). The breadth of fundamental information on ecology and taxonomy, combined with their higher societal importance compared to other freshwater taxa, makes freshwater fish a popular target taxon in assessments of ecological integrity (Simon \& Evans, 2017). Correspondingly, freshwater fishes are commonly used for evaluating the functioning and status of freshwater ecosystems and habitat quality. These assessments, however, are only as good as the data that underpin them. For this reason, effective and meaningful monitoring of fish populations and communities in freshwater habitats is essential.

The need for effective monitoring in ecological research is well-recognized and there are many monitoring programmes that have provided important scientific advances and crucial information for environmental policy (Lovett et al., 2007). For example, freshwater fish monitoring has highlighted changes in species diversity and species status in rivers and lakes (e.g. Counihan et al., 2018; Holmgren et al., 2016; Wagner et al., 2014), played a central role in fish-based assessment systems (e.g. for 
the European Water Framework Directive, Pont et al., 2007), and resulted in guidelines on standardized fish sampling methods (e.g. Bonar et al., 2009).

There remains a series of issues and knowledge gaps with how these programmes are designed and implemented. In particular, freshwater fish monitoring that has been poorly planned and lacks focus results in ineffective programmes that rarely meet their aims (Lindenmayer \& Likens, 2009, 2010; Marsh \& Trenham, 2008; Nichols \& Williams, 2006). Moreover, there is considerable disparity across developed and developing regions in how monitoring schemes are implemented. This is an acute problem, as developing regions are often characterised by high levels of fish diversity but limited resources for research (e.g. Vörösmarty et al., 2010). Where monitoring programmes are in place, there are almost inevitably trade-offs in temporal and spatial scales of measurement (Pollock et al., 2002), but these trade-offs are often poorly quantified or justified, resulting in long-term data lacking statistical power. Finally, there are inherent issues over programmes being either question driven or mandated, with the latter often lacking rigour in design resulting in their provision of only coarse-level summaries of change (Lindenmayer \& Likens, 2010).

In this review, we examine these issues and knowledge gaps, and make recommendations about how they can be addressed within monitoring programmes. Our aim is to foster improved practices by: a) summarizing key questions that monitoring can address when aims are clear, and the approach is rigorous (Section 3 and 4); b) synthesising issues related to sampling design and statistical models, and indicating how they might be overcome (Section 5); c) reviewing different monitoring and sampling approaches (Section 6); d) considering challenges related to species' detectability, taxonomy, economical costs, and ethics (Section 7); and, e) discussing the importance of the appropriate management of monitoring data (Section 8).

\section{History of fish monitoring}

The long history of monitoring programmes is reflected in the scientific literature (Fig. S1.1). Early, though presumably less systematic, efforts in freshwater fish monitoring recorded temporal changes in fisheries, such as reports of Atlantic salmon (Salmo salar, Salmonidae) declines in a central European river that date back to the $18^{\text {th }}$ century (reviewed by Wolter, 2015). The 20th century marked a shift towards systematic sampling with the majority of fish monitoring programmes being established before 1979 (Mihoub et al., 2017). Despite this and in contrast to other taxonomic groups such as birds, mammals, and many plants, freshwater fish are generally under-represented in contemporary biodiversity studies and monitoring programmes (Mihoub et al., 2017; Troudet et al., 2017). This underrepresentation of fish, despite their high diversity, might be explained partly by the fact that they occur in aquatic environments. Thus, in contrast to many terrestrial biota, which can be monitored by visual observations and where community scientists (also known as citizen scientists) can be easily recruited (Thomas, 1996), fish require more specialized sampling methods. However, one feature shared with other taxa is that the spatial extent of fish monitoring is highly biased, being concentrated in the Global 
North (Fig. 1). Freshwater ecosystems (e.g. lacustrine and fluvial habitats) are also generally neglected in fish monitoring programmes, compared to the marine environments (Fig. 1). A further issue is that even when freshwater fish are monitored, the resulting data are often not published or electronically archived, and thus are often inaccessible to the broader scientific community (Lindenmayer \& Likens, 2009; Revenga et al., 2005).

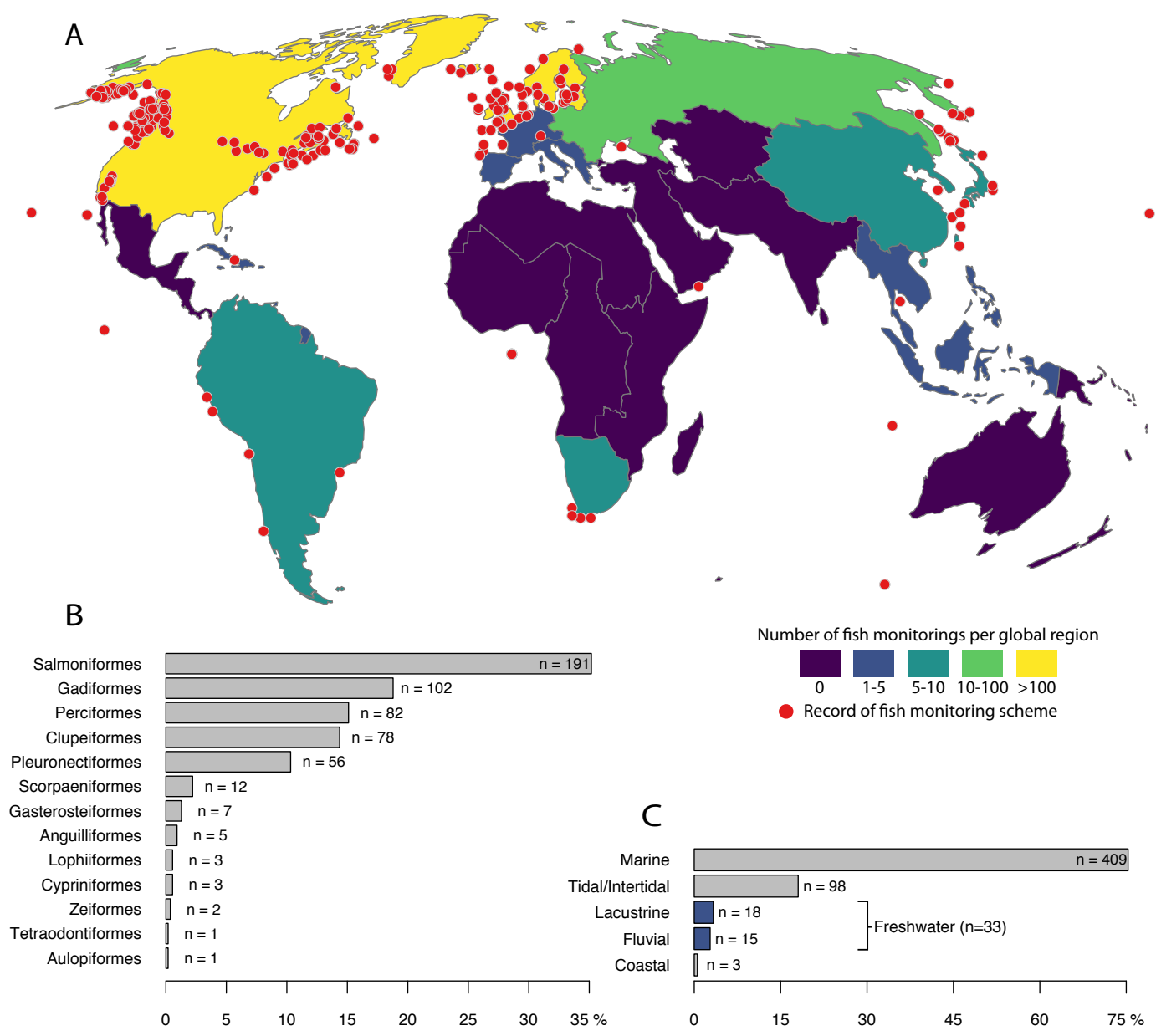

Fig. 1. Overview of fish monitoring programmes across global regions (A), taxonomic orders (B), and biotope types (C) based on records of the taxonomic group Osteichthyes $(n=543)$ in the Global Population Dynamics Database (GPDD, version 2.0, released 2010, www.imperial.ac.uk/cpb/gpdd2, NERC Centre for Population Biology, Imperial College, 2010). Note: The apparent lack of monitoring in, for example, Africa and Australia might reflect a limitation of the database rather than an actual lack of monitoring.

\section{Aims of effective monitoring}

As it is now widely recognised, ecological communities experience continuous temporal turnover, i.e. change in species composition and abundances (e.g. Darwin, 1859; MacArthur \& Wilson, 1967). Some degree of temporal turnover is necessary to maintain ecosystem functions and properties. However, the rate of temporal turnover in contemporary assemblages exceeds the baseline predicted by 
ecological theory (Dornelas et al., 2014). Consequently, the overall goal in effective monitoring of freshwater fish should not be limited to documenting change per se, but should also address the drivers of the observed change (thereby identifying potential remedies).

There are a number of definitions of monitoring in conservation, ecological, and aquatic contexts (Supporting Information Table S1.1). Here, we define freshwater fish monitoring as repeated, field-based measurements of fish that are collected in a systematic manner, allowing the potential detection of important shifts at population or community levels. Therefore, effective monitoring requires a clear set of specific objectives linked to the overall goal of detecting systemic shifts in fish populations or communities over time and space, and so should utilise methodologies and sampling effort that provide the data and statistical power sufficient to meet these objectives.

\section{Different questions lead to different monitoring approaches}

Monitoring programmes need a rigorous design and protocol for collection of data over a sufficiently long period to ensure sufficient statistical power to detect trends or changes and to enable the answering of the motivating questions (Lindenmayer \& Likens, 2010; Nichols \& Williams, 2006). Irrespective of the motivating question, freshwater fish monitoring should generally help to advance ecosystem understanding and provide information needed to identify potential remedies, requiring the detection of significant changes at the community level (e.g. quantifying trends in species richness, temporal $\alpha$ - and $\beta$-diversity, functional diversity, food web structure), and/or at the population level (e.g. quantifying trends in population size and dynamics, abundance of keystone, threatened or non-native species, genetic diversity, species ranges, fisheries stocks, size and age structure, behaviour, phenology, growth, shape, and/or condition). An exception to this might be in mandated-monitoring programmes where highly specific data (e.g. on species presence, abundance, and/or age structure) are compared against predetermined standards (Alexander, 2008; Hellawell, 1991; Hurford, 2010), such as in the Water Framework Directive of the European Union (Birk et al., 2012). In a restoration context, monitoring often aims at assessing the success of implemented measures (Kershner, 1997). Thereby, monitoring is not a stand-alone activity; it contributes to conservation-oriented science and is used to inform structured decision-making processes in conservation management (Nichols \& Williams, 2006).

It is the question(s) that determine the design of a monitoring programme. Some questions can be addressed with species-specific presence-only data, while others might require sampling of an entire community (Table 1). The latter case may utilise a range of capture methods (Zale et al., 2012) that can, in turn, help assess the spatial behaviour, trophic ecology, and genetic characteristics of individuals (Lucas \& Baras, 2000; Lundqvist et al., 2010). Alternative sampling methods include more 
recent approaches such as community science and the use of social media/crowdsourced science (Section 6). The data needs associated with a suite of key monitoring questions are summarised in Table 1. We stress the importance of programmes clearly articulating their questions as this ensures that the sampling design can generate the data required to answer them. As a minimum, there should be identification of what needs to be measured (e.g. fish abundance, fish attributes), the spatial and temporal scope of the programme (e.g. duration, scale; $c f$. Dixon \& Chiswell, 1996); the criteria for reliability (e.g. precision, power); and the practical constraints (e.g. human resources, costs, social conflicts). 


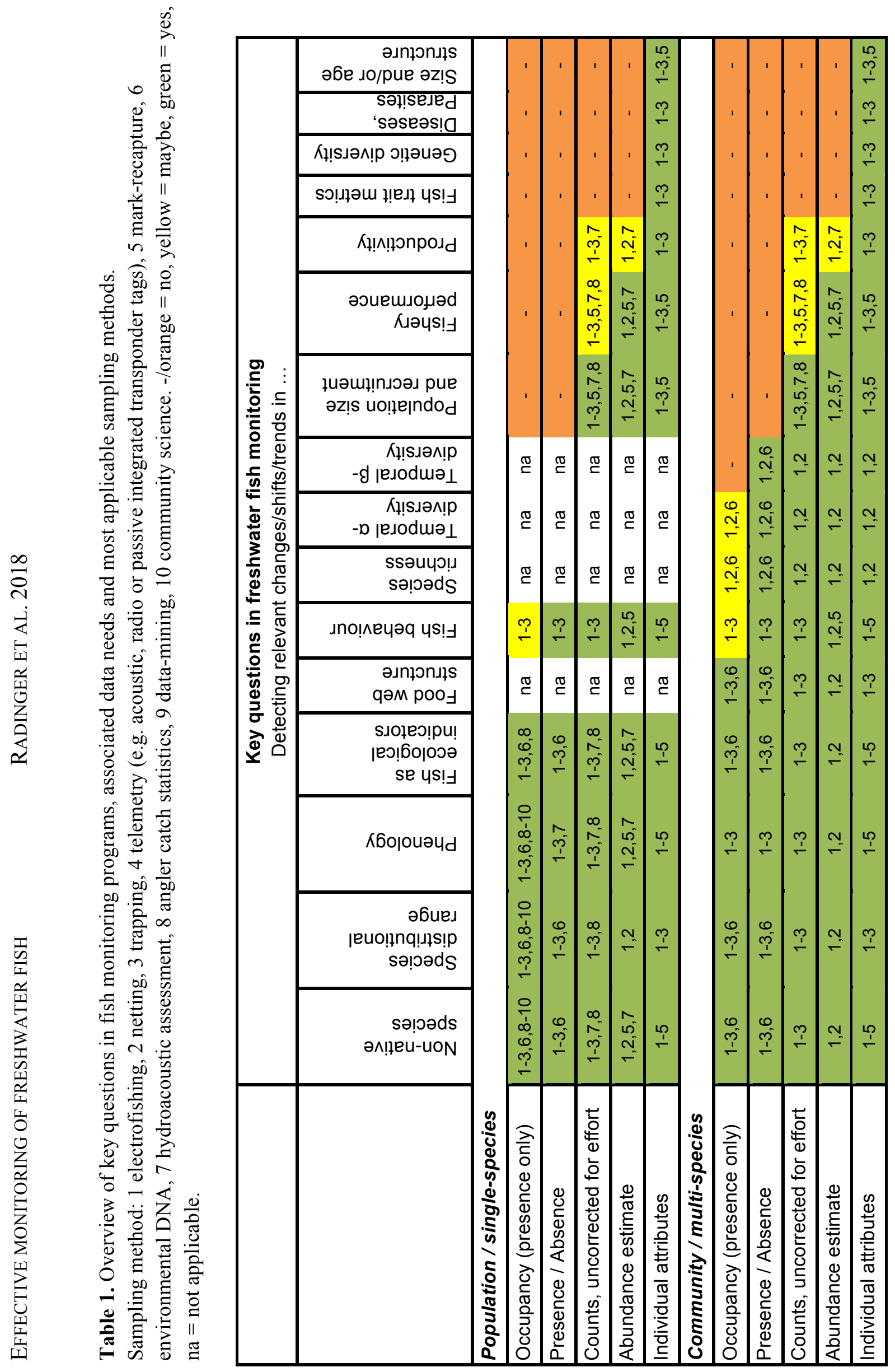




\section{Sampling and network design, and statistical models}

Sampling design relates to the temporal frequency of sampling within a designed network that comprises a series of spatially segregated sites. As such, decisions need to be made regarding how to allocate monitoring effort within and among years, and across sites (Larsen et al., 2001). Two major principles, the avoidance of bias in the selection procedure and achievement of high precision, should underlie the design (Crawford, 1997). A sampling design can be based on probabilistic or non-probabilistic methods. Probabilistic designs include simple random sampling, systematic sampling, and stratified random sampling, with the latter two being more appropriate for heterogeneous, hierarchically-structured aquatic environments, such as river drainages (Lowe et al., 2006; Thorp et al., 2006). However, in fish monitoring, sample sites are frequently selected nonprobabilistically, often based on judgment or convenience (Pope et al., 2010; Wilde \& Fisher, 1996). Irrespective of this, decisions on the design of the programme should be based on a priori defined statistical models that can reliably answer the questions motivating the monitoring programme, such as those related to quantifying community structure, species abundance or other population parameters (e.g. age structure). These questions require consideration during design phases as well as additional resources and time, separate from the monitoring programme itself, for completion.

Where the aims are to detect changes related to (local) management actions such as habitat restoration, or to impact assessment, before-after control-impact (BACI) designs are frequently used (Osenberg et al., 2006; Stewart-Oaten \& Bence, 2001; Thiault et al., 2017). Here, a priori power analyses (Legg \& Nagy, 2006; Marsh \& Trenham, 2008; Maxwell \& Jennings, 2005; Peterman, 1990) can guide the estimation of the minimum number of samples needed to detect a certain effect size (or minimum detectable difference) according to a desired level of significance (Peterman, 1990; Steidl et al., 1997).

However, as fish monitoring programmes are typically undertaken to detect temporal changes in populations over potentially larger scales (Cowx et al., 2009), statistical control and replication designs are often unfeasible (Carpenter et al., 1989; Hargrove \& Pickering, 1992; Schindler, 1998; Turner et al., 2001). Advanced Bayesian (hierarchical) models (Hobbs \& Hooten, 2015) offer useful alternatives, especially when working with imperfect datasets and/or uncertainty associated with sampling and observation, as it is often the case in fish monitoring. For example, Wenger et al. (2017) applied a Bayesian approach to predict the viability of multiple (potentially isolated) populations of Lahontan cutthrout trout (Oncorhynchus clarkii henshawi, Salmonidae); this approach enabled predictions to be made in minimallysampled or even un-sampled populations. Other applications of Bayesian models to analyse monitoring data include estimations of occupancy and richness of fish while accounting for imperfect detection (Bayley \& Peterson, 2001; Coggins et al., 2014), and for relating environmental drivers to stream fish population dynamics (Letcher et 


\section{al., 2015; Wheeler et al., 2018).}

The spatial structure of dendritic networks, and their associated connectivity and directionality, make river systems particularly challenging for monitoring. The effect of spatial variability can be reduced by stratified random sampling, i.e. the proportional sampling of strata that represent different habitat units (Downes et al., 2002) and is widely used in aquatic ecosystems (Dukerschein et al., 2011; Haxton, 2011; Wilde \& Fisher, 1996). More recently, Spatial Stream Network (SSN) models have been developed to better capture the continuous nature of rivers (Fausch et al., 2002) and to account for the spatially autocorrelated relationships between locations within a stream network (Isaak et al., 2014). For example, Isaak et al. (2017) analysed a large fish density dataset using SSN models to obtain population estimates for trout species from 108 sites in a $735 \mathrm{~km}$ river network. The SSN methodology is accessible via the statistical tools 'STARS' (Peterson \& Ver Hoef, 2014) and 'SSN' (Ver Hoef et al., 2014).

In a systematic sampling design, the first sample site is chosen randomly and all subsequent samples are regularly placed in space or time (Conroy \& Carroll, 2009; Quinn \& Keough, 2002). A systematic design is useful when investigating effects of environmental gradients. A recent development in this context is the Generalized Random Tessellation Stratified (GRTS) design (Stevens \& Olsen, 2003, 2004), available from the statistical package 'spsurvey' (Kincaid \& Olsen, 2016). GRTS allows design-based inferences to entire areas based on spatially-balanced samples, i.e. a spatial distribution of sample locations that balances the advantages of simple or stratified random samples or systematic samples (Larsen et al., 2008). GRTS has been evaluated as reliable and cost-effective, for example, for monitoring North American salmonids (Gallagher et al., 2010).

The adaptive approach (Box 1) argues that the sampling design should be reevaluated and re-designed as necessary as data are gathered and their variability analysed. An analysis of the components of variance and their influence on trend detection capability can help in preparing design-efficient trend monitoring networks (Larsen et al., 2001). This ensures that changes in the chemical, physical, or biological conditions are accounted for in the sampling design (Buckland et al., 2012; Strobl \& Robillard, 2008).

\section{Box 1. Adaptive monitoring}

There is often high uncertainty and complexity in the drivers of fish community change that can range from global environmental change (e.g. climate change; Graham \& Harrod, 2009; Radinger et al., 2016) to more local issues (e.g. altered flow regimes; Harby et al., 2007). Monitoring programmes must be capable of providing data suitable for the continued management of the resources (Polasky et al., 2011). The informed decision-making process of adaptive monitoring (sensu Lindenmayer \& Likens, 2009) enables monitoring programmes to evolve in response to new questions, information, situations, or conditions or the development of new protocols (Lindenmayer et al., 2011). Adaptive monitoring is considered a long-term activity closely related to scientific research and management. The ultimate aim of 
any adaptive monitoring programme is to demonstrate that new insights gained through its application will improve management practices (Lindenmayer et al., 2011), potentially leading to increases in the effectiveness of monitoring for conservation.

An example of adaptive monitoring is outlined by Fölster et al. (2014) for Swedish fresh waters. At the outset the early naturalists measured specific and localized natural phenomena such as the relationship between macrophytes and lake water chemistry (Lohammar, 1938). However, the scope of the freshwater monitoring programme in Sweden and the number of monitored sites increased along with the emergence of new challenges related to, for example, eutrophication in the 1960s, acid rain in the 1970s, and the EU Water Framework Directive in 2000. Today, the program consists of regular long-term monitoring of water chemistry and biodiversity (including freshwater fish) in 114 streams and 110 lakes (Fölster et al., 2014). This example not only illustrates the value of adaptive monitoring by providing long-term data to understand and overcome many of the emerging environmental problems, but also emphasizes its potential to investigate future challenges, e.g. related to climate change, testing resilience theory, or predicting regime shifts and tipping points.

\section{Approaches to fish monitoring}

\subsection{Monitoring questions versus sampling methods}

The numerous sampling methods that can be utilised for fish monitoring, including capture and non-capture techniques, have been extensively reviewed (e.g. Bonar et al., 2009; Joy et al., 2013; Zale et al., 2012). Capture methods involve the physical removal of fish from the water to enable species identification, and the collection of biometric data (e.g. length, weight) and hard structures (e.g. scales) for ageing the fish to determine population demographics and dynamics. The most common methods available for capturing freshwater fish include electrofishing, netting, and trapping (Bonar et al., 2009). Non-capture methods (e.g. hydroacoustic surveys) can provide data complementary to capture techniques. They can also be used where capture methods lack sufficient power to provide robust estimates of population abundances (Hughes, 1998; Lyons, 1998). However, a feature of some non-capture methods is their taxonomic ambiguity due to either their lack of fish capture (Boswell et al., 2007) (Section 6.4) or through erroneous identification of specimens (Section 7.2).

The application of a sampling method in monitoring might differ markedly according to the programme's aims. For example, electrofishing can be applied within point abundance sampling designs that can be effective for monitoring the diel activity of (small) fishes (reviewed by Copp, 2010) or the status of rare species (e.g. the critically endangered European eel, Anguilla anguilla, Anguillidae; Laffaille et al., 2005). However, capturing fish in longer river reaches using electrofishing might be more suitable where the monitoring aim is to assess biological/ecological integrity, as 
biotic indices require data at multiple organization levels, from size structure to assemblage richness (e.g. Noble et al., 2007; Pont et al., 2007; Schmutz et al., 2000), often in conjunction with data on habitat quality (e.g. Van Liefferinge et al., 2010; Milner et al., 1998).

\subsection{Capture techniques and application within monitoring programmes}

The challenge of ensuring that capture methods are fit for purpose, such as evaluating the composition of an assemblage (details in Box 2) (e.g. Zale et al., 2012), has resulted in a series of standardised protocols being made available for sampling inland fish populations in many areas of the world, including Europe, North America, and New Zealand (Bonar et al., 2009; CEN, 2003, 2006; Joy et al., 2013; Table S4.1). Standardization not only refers to the equipment used or how it is used, but also to the timing of sampling, the habitats that are sampled, and effort applied (Bonar et al., 2011). Standardizing the collection and reporting of fish monitoring data offers many advantages including an improved ability to compare data across regions or time, improved communication across political boundaries, and the control of bias associated with different sampling techniques (Cooke et al., 2016). Standardization in fish sampling has been considered an important step forward in managing long-term data and assessing efficacy of large spatial scale management strategies (Bonar et al., 2017). This is of particular relevance in monitoring programmes where many researchers combine datasets to jointly address questions over time and space. For a comprehensive overview on standardisation of fish sampling across sampling gears and aquatic environments, see Bonar et al. (2009).

Two fundamental concepts have emerged in relation to the application of capture techniques and protocols to fish monitoring: the importance of sampling design (discussed earlier in Section 5) and response design (Stevens \& Urquhart, 2000).

Response design incorporates decisions about how to measure the fish community and population metrics with accuracy and precision (Pollock et al., 2002). For example, where assessments of age structure, growth rates, and recruitment are required, then decisions are needed on the ageing method, such as whether to rely on length-frequency analyses or collect hard structures, such as scales, from captured fishes (e.g. Hamidan \& Britton, 2015). If scales are collected, then decisions are needed regarding how many individual fish need to be sampled and over what size range (Busst \& Britton, 2014). In addition, where hard structures are being used for ageing, the frequency of annulus formation might need validating to maximise accuracy (Beamish \& McFarlane, 1983), requiring regular sampling throughout the year or mark-recapture methods (Britton et al., 2010; Chisnall \& Kalish, 1993). Scale samples for fish ageing, and tissue samples for genetic and stable isotope analyses, can be collected from fish captured by anglers to complement on-going monitoring (Gutmann Roberts et al., 2017). 


\section{Box 2: Sampling effort and biodiversity estimation}

Decisions about the spatial extent and duration of sampling have important implications. If the goal is to quantify an attribute of a population of interest, then, all other things being equal, estimates of abundance will scale predictably with effort. There are a range of statistical techniques, such as removal sampling (Southwood \& Henderson, 2000), that can be used to estimate population size and/or to ensure that effort is adequate for the intended purpose. It is relatively straightforward, therefore, to compute trends for single populations.

If, on the other hand, the aim is to quantify compositional turnover (temporal $\beta$-diversity), or to calculate a metric of $\alpha$-diversity, such as assemblage richness, it is essential that any temporal or spatial comparisons take account of the inherent unevenness of ecological assemblages. Although the number of individuals (across all species) will typically increase linearly if an assemblage is sampled over a longer time period, or the area sampled is increased, the species accumulation curve will gradually flatten (Fig. 2). As a result, any metrics that either explicitly or implicitly depend on richness cannot be scaled by simple multiplication or division. Species richness is the metric most obviously influenced by this, but most biodiversity indices, including, for example, the Berger-Parker dominance metric (Magurran, 2004, 2011; Magurran \& McGill, 2011) and Jaccard similarity (Baselga, 2010), are also affected.

Fortunately, there are statistical solutions to this problem. Rarefaction is the traditional way of making fair comparisons across assemblages or of community diversity over space or time (Gotelli \& Colwell, 2001, 2011). In essence, the samples (or assemblages) are rarefied to the smallest common sampling effort. Rarefaction can be computed in relation to the minimum number of individuals sampled, or to the smallest number of sampling units. While most rarefaction analyses focus on species richness, in principle many different biodiversity metrics can be rarefied. In the case of temporal or spatial $\beta$-diversity comparisons, the investigator should use samplebased rarefaction as this automatically retains the identity of the species involved. A recent innovation is to extrapolate to the largest sample size rather than rarefy to the smallest one (Chao et al., 2014; Hsieh et al., 2016). Rarefaction can also be used to make informed comparisons about community structure and composition using null model approaches (Cayuela et al., 2015; Cayuela \& Gotelli, 2014). In summary then, any computation of trends in community $\alpha$-diversity or $\beta$-diversity should either be based on sampling that has been rigorously standardized or data that have been statistically standardized (by rarefaction or similar) - see Fig. 2 for an example. 

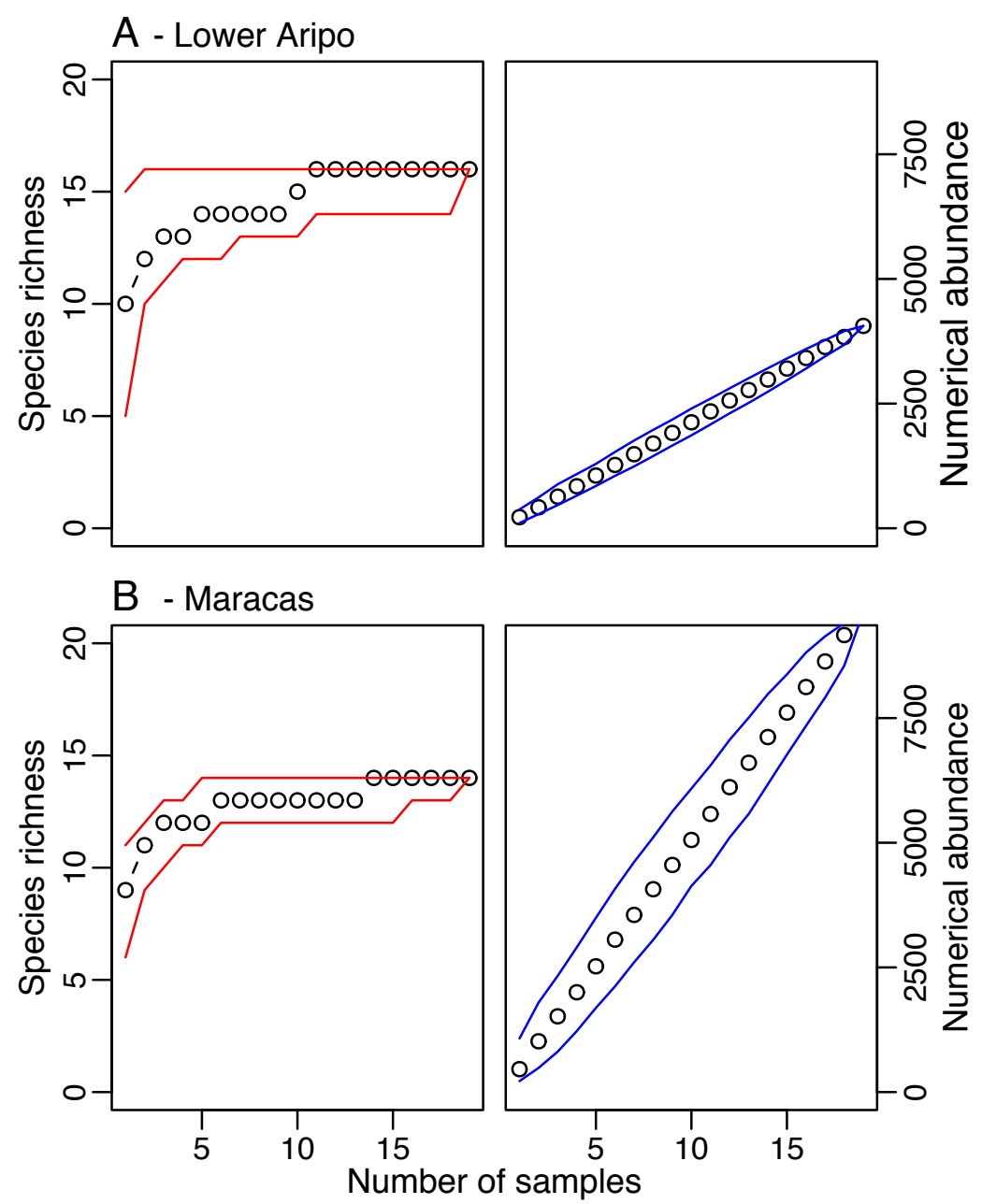

Fig. 2. Illustration of the variation of the number of species (species richness) and numerical abundance with sampling effort. The data are for two river sites in Trinidad (top - (A) Lower Aripo, bottom - (B) Maracas, sampled four times annually for five years. The data are described in Magurran et al. (2018). In each case the species (and numerical abundance) accumulation curves are constructed by randomly shuffling the temporal order of the samples a 1000 times. The open points represent the median value of the randomised accumulation curves; their $95 \%$ confidence limits ( 0.025 and 0.975 quantiles) are also shown (species richness - left column; numerical abundance - right column).

\subsection{Capture and release methods}

It is often desirable to release captured fish, unharmed, to the site of capture, without further intervention. However, attaching tracking devices or marking fish, prior to release, can substantially increase the amount of information obtained. For example, biotelemetry using acoustic, radio, or passive integrated transponder tags (Cooke et al., 2011; Thiem et al., 2011) can reveal individual variability in movements and behaviours within and between populations (Lucas \& Batley, 1996; Radinger \& Wolter, 2014), elucidate population mixing and gene flow (Huey et al., 2011), assess the effects of connectivity and habitat fragmentation on river fishes (Capra et al., 2017; Lin et al., 2018), and help evaluate management units for fisheries or conservation (Funk et al., 2012). 
Mark-recapture studies can also strongly complement fish monitoring by providing alternative estimates of population size and fish ages (Hamel et al., 2015; Sass et al., 2010). They can also reveal the extent of migrations of individual fish between habitats within specific populations (Sandlund et al., 2016).

\subsection{Non-capture monitoring techniques}

Non-capture monitoring methods to complement capture data include environmental DNA and hydroacoustic assessments. These methods are often applied within monitoring programmes to provide data on different components of the community or population, and are especially useful for larger water bodies where capture techniques are often difficult to apply or are inefficient.

Environmental DNA ('eDNA' hereafter) is based on the presence DNA of fishes in water samples originating from mucus and faeces, the sloughing off of cells from their gut lining, and the decomposition of dead individuals (Davison et al., 2016; Jerde et al., 2011; Turner et al., 2015). DNA is extracted from water samples, and polymerase chain reaction (PCR) used in conjunction with species-specific genetic markers to amplify DNA fragments to indicate the presence of target species (Turner et al., 2015). The method is increasingly being applied to the monitoring of freshwater species (Fig. S1.1), including those of conservation importance (Takahara et al., 2012; Thomsen et al., 2012).

There are two basic ways that eDNA can be applied in a fish monitoring programme. Water samples can be analysed to detect the presence of a specific species, or can be screened for whole communities of organisms using 'eDNA metabarcoding' (Hänfling et al., 2016; Lawson Handley, 2015). Recent refinements have improved the reliability of species' detection (Hänfling et al., 2016), but some questions remain, for example, on factors affecting the rate of DNA breakdown in the environment (Barnes et al., 2014). However, the non-detection of speciesspecific DNA fragments in a sample of river water does not necessarily imply the absence of the target species, nor does a positive signal necessarily imply that the species is present, as eDNA could have been transported from upstream areas (Roussel et al., 2015). Nevertheless, as refinements in the technique continue, it should increasingly provide a strong complement to capture methods, especially in regions where knowledge on the species likely to be present is available. Although issues over the reliability of eDNA to provide estimates of abundance are being addressed, they remain highly challenging (Lacoursière-Roussel et al., 2016). One important consideration will be the integration of data collected using traditional methods with inferences about fish communities obtained using eDNA (see 6.6 below).

Hydroacoustic assessments involve the application of an acoustic beam from a transducer through the water. Any fish within the beam returns a signal, with the target strength of the returning signal indicating the relative size of the fish. Whilst the method generates data on fish density, there is high taxonomic ambiguity in terms of species present, with no biometric data collected (other than conversion of target strengths to approximate fish lengths) (Boswell et al., 2007). Nevertheless, 
hydroacoustic assessments have been used extensively for fish monitoring, especially in lakes where sampling strategies have been developed (e.g. Guillard \& Vergès, 2007), with target strengths related to species-specific attributes to increase knowledge on community composition (Frouzova et al., 2005). In lowland rivers, such as the River Thames and River Trent in England, mobile hydroacoustic techniques have been applied to monitor the spatial and temporal distributions of fish communities (Hughes, 1998; Lyons, 1998). The method has also been applied to assessing the status of endangered fishes (Zhang et al., 2009).

\subsection{Anglers' data and data mining}

Statistics on angler catch rates and species composition have been applied to the monitoring of fish community composition of large lowland rivers where other fish capture methods are either difficult to apply or inefficient (Jones et al., 1995). For example, in the River Trent, England, angler catch statistics monitored changes in the fish assemblage in relation to improvements in water quality (Cooper \& Wheatley, 1981; Cowx \& Broughton, 1986). More recently, catch statistics from individual anglers were used to assess the population status of mahseer fishes (Tor spp., Cyprinidae) in the River Cauvery, India (Pinder et al., 2015a,b). An issue with anglerbased data is that they tend to be biased for specific species and size ranges (Amat Trigo et al., 2017).

Data mining, where spatial and temporal data on species are gathered through information available from on-line sources, is a different non-capture technique for monitoring changes in the distribution of species. Databases including the Global Biodiversity Information Facility (GBIF; www.gbif.org/), the Global Population Dynamics Database (GPDD; www.imperial.ac.uk/cpb/gpdd2/secure/login.aspx), or VertNet.org enable users to access global distribution records of species via directed searches that provide records with location coordinates for use within GIS. The GPDD also provides data on population dynamics, rather than just distribution data. The FishBase database (Froese \& Pauly, 2018) provides species-level information gathered from the literature, including occurrences and a wide range of ecological data.

An alternative method to using these online databases is monitoring the distribution of fishes via community science, particularly via social media platforms. Indeed, the application of community science and crowd sourcing to the collection of biological data is increasingly frequent (e.g. www.inaturalist.org, Fig. S1.1), thanks to many smartphones now having GPS, high-resolution cameras, and continuous internet connection (Bik \& Goldstein, 2013; Di Minin et al., 2015). For example, for monitoring distributions of non-native fish, a number of smartphone 'apps' are available, with these generally enabling the user to send a geo-referenced image of the species to a specific organisation for validation and recording. Current examples include 'That's Invasive' (http://www.rinse-europe.eu/resources/smartphone-apps/) and 'AquaInvaders' (http://naturelocator.org/aquainvaders.html). Both of these 'apps' also provide users with information and images on specific invaders to facilitate their 
identification of species. Venturelli et al. (2017) have recently reviewed the opportunities and challenges associated with angler 'apps'.

Data can also be sourced from user-generated content on various social media platforms (Di Minin et al., 2015). By data-mining these non-biological sources, such as via searches of specific social media sources (e.g. https://www.youtube.com/), recreational fisheries forums and blogs, and news-media channels, fish distribution and dispersal data can be generated. For example, this approach has been applied successfully to assessments of non-native fish invasions, such as perch (Perca fluviatilis, Percidae) and channel catfish (Ictalurus punctatus, Ictaluridae) in Portugal (Banha et al., 2015, 2017). Increasingly, these searches can be automated through use of computer code. For example, geo-referenced images and video of specific species within image and video hosting websites (e.g. flickr) can be searched, with GIS interfaces enabling distribution maps to be constructed (see Fig. 3) and thus temporal and spatial distribution patterns better understood (Coding Club, 2018).
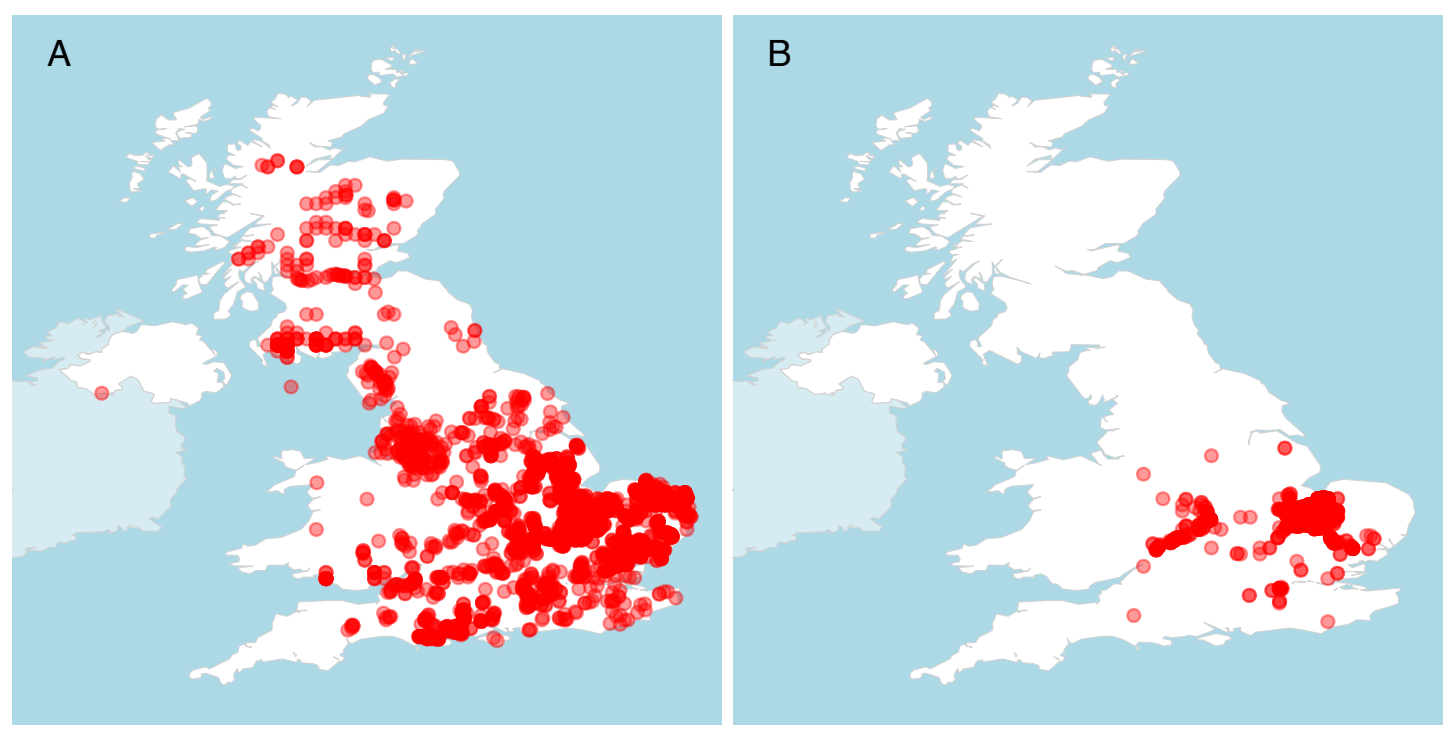

Fig. 3. The distribution of (A) Northern pike (Esox lucius, Esocidae) and (B) Zander (Sander lucioperca, Percidae) in the UK, between 1986 and 2016, based on data from GBIF (www.gbif.org). The R code (R Core Team, 2017) used to construct the figure was adopted from the Coding Club (https://ourcodingclub.github.io/2017/03/20/seecc.html).

\subsection{Complementarity of capture and non-capture methods}

Data acquired from capture and non-capture methods within the same monitoring programme need to be integrated effectively. For example, fish monitoring in Windermere, England, a relatively large and deep glacial lake, has recently been complemented by application of eDNA that recorded the presence of 14 of 16 fish species known to be present, when concomitant gill net surveys only captured four fish species (Hänfling et al., 2016). Windermere has also been monitored regularly for over 60 years by other methods, including fish traps, gillnets, hydroacoustics, and piscivorous fish diet composition (Langangen et al., 2011; Winfield et al., 2008, 2012). The high complementarity of these datasets has 
improved understanding of environmental (e.g. nutrient enrichment, warming) and other changes (e.g. invasive fishes), and illustrated their potential for monitoring other systems (e.g. Vindenes et al., 2014; Winfield et al., 2010).

\section{Major challenges in fish monitoring}

\subsection{Detectability}

Many evaluations of biodiversity, including those of freshwater fishes (Magurran, 2004; Southwood \& Henderson, 2000), assume that individuals have been sampled randomly from the assemblage (Buckland et al., 2011; Pielou, 1975). This is rarely achievable in nature (Pielou, 1975). In many cases, the problem arises because it is difficult (or impossible) to know if a species that is absent from a site or sample is truly absent, or is missing through the ineffectiveness of the sampling method. Thus, it is important to thoroughly consider observation error and capture probabilities and to address issues of detectability and detection bias also in fish monitoring. Potential solutions to issues of detectability have been extensively discussed elsewhere and include modelling occupancy (Bayley \& Peterson, 2001; Iknayan et al., 2014; MacKenzie et al., 2002, 2006; Royle \& Link, 2006; Wenger \& Freeman, 2008), estimating the probability of detection of species (and/or individuals) through markrecapture (Borchers et al., 2002, 2015; Buckland et al., 2011) or distance sampling (Buckland et al., 2001, 2004, 2011), and/or demonstrating that the data are sufficiently robust to address the question posed without further correction (Buckland et al., 2011; Magurran et al., 2018).

\subsection{Taxonomy}

Taxonomic issues can often emerge in biological monitoring programmes, with the most obvious one being taxonomic uncertainty and the risk of species misidentification in the field or the laboratory. For example, Daan (2001) reported extensive species misidentifications in a marine fish database and there are many other cases in the freshwater fish literature (e.g. Hänfling et al., 2005; Serrao et al., 2014; Vidal et al., 2010). Nevertheless, a well-appreciated advantage of fish is that their taxonomy is better known and easier than in most other freshwater groups, such as invertebrates or algae, and thus fish can often be identified in the field without sacrificing individuals. However, this is less likely to be the case in species-rich regions such as the tropics, where the taxonomy is less well known, compared to regions with well-characterised fish faunas.

The extent of species misidentification in more taxonomically challenging groups, such as stream invertebrates, receives greater attention than in freshwater fish. For example, Stribling et al. (2008) compared taxonomic identification of stream macro-invertebrates across eight U.S. laboratories and found means of $21 \%$ taxonomic disagreement. These kinds of errors might also occur in fish monitoring, especially in samples with high species richness or in samples from regions where taxonomy is poorly described. These studies reinforce the importance of adequate 
training and experience, documentation of standard procedures, and routine quality control (Stribling et al., 2003, 2008). Species misidentification is even more important when fishers are interviewed to obtain local knowledge data. Here, thorough validation procedures are essential (Poizat \& Baran, 1997; Valbo-Jørgensen \& Poulsen, 2000).

A similar problem is when taxonomy changes and it is recognised that a single species in fact comprises several cryptic species. This problem is increasingly frequent given the increasing power of molecular tools (e.g. April et al., 2011; Lara et al., 2010; Young et al., 2013). For example, Young et al. (2013) found that the majority of species-level taxonomic units of the genus Cottus (Cottidae) as evaluated by DNA barcoding did not assign to previously recognized species in this region. New taxonomic alignments hinder comparison with old samples if no specimens were preserved. In addition, the same species names may have had different synonyms in the past, meaning that databases need to be carefully revised for inconsistencies and errors. Erroneous sequences and misidentifications are also frequent in GenBank and similar sequence databases (Harris, 2003). It has been estimated that up to $56 \%$ of German freshwater fish species may be incorrectly identified to species level in some databases (Knebelsberger et al., 2015). Consequently, errors in genetics databases might have major adverse impacts on eDNA as a robust technique. It is likely that the frequency of such taxonomic problems in data is more prevalent in monitoring of freshwater fish than in research (Stribling et al., 2003). It is thus important to fully reference the taxonomic resources used in studies, not just as a quality check on methodology, but also to recognize the importance of taxonomy and the work of taxonomists (Santos \& Branco, 2012; Vink et al., 2012; Wägele et al., 2011).

\subsection{Economic costs}

For a monitoring programme to be effective, successful and sustainable over the longer-term, it must not only be ecologically relevant and statistically credible, but also cost efficient, i.e. the perceived benefits of ecological monitoring (e.g. information on trends or status changes) must justify its cost (Caughlan \& Oakley, 2001; Charles et al., 2016; Hinds, 1984). As financial limitations always apply, sustained monitoring requires a proper selection of relevant variables that need to be measured (Braun \& Reynolds, 2012). Often the true costs of monitoring are not recognized and likely underestimated (Caughlan \& Oakley, 2001), and its benefits depend on the value that society gives to the long-term sustainability of freshwater ecosystems. Hence, costs of monitoring need to be contrasted with the costs of not monitoring. These include increased uncertainty in evaluating outcomes and future projections, and the possibility that managers may not detect important shifts until it is too late to effectively address them.

Caughlan \& Oakley (2001) provided a breakdown of monitoring costs, comprising of budgetary expenses related to, for example, data collection, data management, quality assessment, data analysis, reporting and scientific oversight, opportunity costs (i.e. other benefits forgone by allocating resources to monitoring), and external costs (i.e. costs not directly covered by the monitoring programme 
budget). The costs for data collection - which are frequently the largest - may vary depending on the methods applied. While established methods in fish monitoring, such as field-based capture methods (e.g. electrofishing, netting, trapping), are commonly labour intensive in the field and thus costly, the financial costs of emerging methods, such as use of eDNA, the automatized collection of data (e.g. hydroacoustic assessments), and the use of community science and data mining, are often related to post-processing, managing and analysing big data (Section 6.4). A detailed review of the costs associated with ecological monitoring can be found elsewhere (e.g. Caughlan \& Oakley, 2001).

\subsection{Fish welfare and ethics in monitoring}

The importance of ethical issues relating to biological fieldwork and the need to minimize harm to species and ecosystems has repeatedly been emphasized (e.g. Bennett et al., 2016; Costello et al., 2016; Farnsworth \& Rosovsky, 1993); a detailed consideration of these matters is beyond the scope of this review. We note, however, that fish welfare issues have received much attention (e.g. Sloman et al., 2019), often centred around the question of whether fish are sentient and can experience pain and suffering (e.g. Arlinghaus et al., 2007; Braithwaite, 2010; Huntingford et al., 2006, 2007; Rose et al., 2014) - a challenging question that has a number of implications in a scientific, ethical, and legal context (Browman et al., 2019). Browman et al. (2019) argue for a pragmatic approach using objective indicators of stress, health status, and behaviour to inform about fish well-being.

Irrespective of the scientific debate on fish-welfare, institutional requirements and legal regulations need to be considered during freshwater fish monitoring. Fish sampling usually requires specific permits from responsible authorities, particularly when working with protected species or in protected areas. Depending on the aim and sampling method, fish monitoring might involve the capture and treatment of fish or might even require methods of destructive sampling, i.e. the killing of fish (e.g. Blessing et al., 2010), such as when individuals require taxonomic identification in the laboratory, including where voucher specimens are required (Bortolus, 2008; Rocha et al., 2014; Section 7.2). However, alternative methods of identification should be used to avoid collection of rare species (Costello et al., 2016; Minteer et al., 2014). Protocols for fieldwork (e.g. Barbour et al., 1999; Brenkman et al., 2008; CCME, 2011; Cowx et al., 2009; Cowx \& Fraser, 2003; Joy et al., 2013) typically provide guidelines on appropriate and least invasive techniques (e.g. non-capture techniques such as hydroacoustics and eDNA where applicable, Section 6.4) and are designed to minimize stress or damage caused by catching, handling, and holding. Developmental stage and species differences are also taken into account. The sampling method and design should consider trade-offs of the potential harm to fish versus the quality of the obtained data in relation to sampling efficiency. In particular, when capture techniques are applied, potential cumulative effects should be paid specific attention as fish monitoring involves repeated sampling of species that can be long-lived ( $>20$ years) and is often targeted for protected or endangered species (Benejam et al., 2012). For example, an efficient and common capture technique such 
as electrofishing might cause sub-lethal injuries that are often not externally obvious and possibly fatal (Snyder, 2003). Moreover, ethical issues related to fish monitoring extend beyond fish-welfare and must also consider impacts on non-target species and ecosystems or the potential transmission of pests and/or invasive species (Costello et al., 2016).

\section{Management of monitoring data}

For the sustainable success of a monitoring programme and to potentially infer future changes, policies and procedures that guarantee the quality of data capture, documentation, and preservation for long-term use is required (Michener, 2015; Michener \& Jones, 2012; Rüegg et al., 2014; Sutter et al., 2015). For example, Vines et al. (2014) found that the availability of research data declines with article age, with the probability of finding the dataset decreasing by $17 \%$ per year.

Although the importance of integrating data management into long-term ecological (monitoring) projects has been emphasized repeatedly in previous papers (Costello \& Wieczorek, 2014; Sutter et al., 2015), this is often a neglected area in freshwater fish studies (but see Moe et al., 2013; Peterson et al., 2013 for some examples). Thoroughly considering data management to preserve data for long-term use and accessibility (even beyond the lifetime of the work that generated them) will require more time and resources to fish monitoring programmes and should be considered at the earliest stages and accounted for in budgetary plans.

Data management is not limited to 'what' was collected (i.e. fish sampling data); many other data often associated with sampling, such as geospatial information, multimedia content, voucher specimens, associated environmental variables, and other biological data, also need to be considered (Costello \& Wieczorek, 2014). Furthermore, to ensure the utility of a dataset, it must be accompanied by metadata, i.e., a detailed description of who created the data, when and where the data were collected and stored, how and why the data were generated, processed, and analysed (Michener, 2006).

Data management is a key element in freshwater fish monitoring programmes. A detailed discussion of challenges and opportunities of data management, as well as practices of how it can or should be implemented in fish monitoring is provided elsewhere (Costello et al., 2013; Costello \& Wieczorek, 2014; Michener \& Brunt, 2000; Reichman et al., 2011; Sutter et al., 2015).

\section{Conclusions}

Given the rapid environmental degradation of the Earth's freshwater ecosystems and associated unprecedented rates of biodiversity change, the importance of robust, replicable, and effective programmes to monitor freshwater fish has never been higher. Future challenges related to habitat degradation, climate and land use change, and biological invasions necessitate monitoring programmes that systematically collect quality data allowing the potential detection of systemic shifts of populations 
or communities and thereby improve our understanding of ecosystem responses to environmental change. There is a pressing need for effective monitoring to comprehensibly quantify biodiversity change and to inform evidence-based environmental decision-making.

At a minimum, when establishing a monitoring programme, clear articulation of the monitoring aim(s) is essential and should address: (i) what should be monitored and how; (ii) how to allocate effort within time and across sites; (iii) establish criteria for data reliability; and (iv) identify practical constraints.

Monitoring must also take into account issues related to the detectability of species, taxonomy, and animal welfare. Additionally, monitoring programmes must integrate data management practices that ensure the quality of data capture, documentation, and preservation of information for long-term use and re-use.

In summary, careful reflection on aims(s) and the extent to which the data collected will meet these aims will greatly improve the quality and usefulness of monitoring data. Consistently high monitoring standards will improve data comparability within and amongst countries and systems. Finally, effective monitoring of freshwater fish will advance our overall understanding of freshwater ecosystems and contribute to the preservation and management of freshwater fish diversity while helping mitigate anthropogenic impacts. 


\section{Acknowledgments}

This paper is based on a workshop funded by the Spanish Ministry of Science, Innovation and Universities (project CGL2015-69311-REDT). Additional financial support was provided by the same ministry (projects: ODYSSEUS, BiodivERsA32015-26, PCIN-2016-168; and CGL2016-80820-R) and the Government of Catalonia (ref. 2014 SGR 484 and 2017 SGR 548).

\section{References}

Alexander, M. (2008). Management Planning for Nature Conservation - A Theoretical Basis \& Practical Guide. Dordrecht: Springer.

Allan, J.D., Abell, R., Hogan, Z., Revenga, C., Taylor, B.W., Welcomme, R.L., \& Winemiller, K.O. (2005). Overfishing of inland waters. BioScience, 55, 1041-1051. doi: 10.1641/00063568(2005)055[1041:OOIW]2.0.CO;2.

Amat Trigo, F., Gutmann Roberts, C., \& Britton, J.R. (2017). Spatial variability in the growth of invasive European barbel Barbus barbus in the River Severn basin, revealed using anglers as citizen scientists. Knowledge \& Management of Aquatic Ecosystems, 418(17):1-6. doi: 10.1051/kmae/2017009.

April, J., Mayden, R.L., Hanner, R.H., \& Bernatchez, L. (2011). Genetic calibration of species diversity among North America's freshwater fishes. Proceedings of the National Academy of Sciences, 108, 10602-10607. doi: 10.1073/pnas.1016437108.

Arlinghaus, R., Cooke, S.J., Schwab, A., \& Cowx, I.G. (2007). Fish welfare: a challenge to the feelings-based approach, with implications for recreational fishing. Fish and Fisheries, 8, 57-71. doi: 10.1111/j.1467-2979.2007.00233.x.

Banha, F., Ilhéu, M., \& Anastácio, P.M. (2015). Angling web forums as an additional tool for detection of new fish introductions: the first record of Perca fluviatilis in continental Portugal. Knowledge and Management of Aquatic Ecosystems, 416, 03. doi: 10.1051/kmae $/ 2014039$.

Banha, F., Veríssimo, A., Ribeiro, F., \& Anastácio, P.M. (2017). Forensic reconstruction of Ictalurus punctatus invasion routes using on-line fishermen records. Knowledge \& Management of Aquatic Ecosystems, 418(56):1-8. doi: 10.1051/kmae/2017045.

Barbour, M.T., Gerritsen, J., Snyder, B.D., \& Stribling, J.B. (1999). Rapid bioassessment protocols for use in streams and wadeable rivers: periphyton, benthic macroinvertebrates, and fish. Washington: EPA 841-B-99-002, U.S. Environmental Protection Agency; Office of Water.

Barnes, M.A., Turner, C.R., Jerde, C.L., Renshaw, M.A., Chadderton, W.L., \& Lodge, D.M. (2014). Environmental conditions influence eDNA persistence in aquatic systems. Environmental Science \& Technology, 48, 1819-1827. doi: 10.1021/es404734p.

Baselga, A. (2010). Partitioning the turnover and nestedness components of beta diversity. Global Ecology and Biogeography, 19, 134-143. doi: 10.1111/j.1466-8238.2009.00490.x.

Bayley, P.B., \& Peterson, J.T. (2001). An Approach to Estimate Probability of Presence and Richness of Fish Species. Transactions of the American Fisheries Society, 130, 620-633. doi: 10.1577/1548-8659(2001)130<0620:AATEPO>2.0.CO;2.

Beamish, R.J., \& McFarlane, G.A. (1983). The forgotten requirement for age validation in fisheries biology. Transactions of the American Fisheries Society, 112, 735-743. doi: 10.1577/15488659(1983)112<735:TFRFAV>2.0.CO;2.

Benejam, L., Alcaraz, C., Benito, J., et al. (2012). Fish catchability and comparison of four electrofishing crews in Mediterranean streams. Fisheries Research, 123-124, 9-15. doi: 10.1016/j.fishres.2011.11.022.

Bennett, R.H., Ellender, B.R., Mäkinen, T., et al. (2016). Ethical considerations for field research on fishes. Koedoe, 58, 1-15. doi: 10.4102/koedoe.v58i1.1353. 
Bik, H.M., \& Goldstein, M.C. (2013). An introduction to social media for scientists. PLoS Biology, 11, e1001535. doi: 10.1371/journal.pbio.1001535.

Birk, S., Bonne, W., Borja, A., et al. (2012). Three hundred ways to assess Europe's surface waters: An almost complete overview of biological methods to implement the Water Framework Directive. Ecological Indicators, 18, 31-41. doi: 10.1016/j.ecolind.2011.10.009.

Blessing, J.J., Marshall, J.C., \& Balcombe, S.R. (2010). Humane killing of fishes for scientific research: a comparison of two methods. Journal of Fish Biology, 76, 2571-2577. doi: 10.1111/j.1095-8649.2010.02633.x.

Bonar, S.A., Fehmi, J.S., \& Mercado-Silva, N. (2011). An onverview of sampling issues in species diversity and abundance surveys. In A. Magurran and B. McGill (Eds) Biological Diversity: Frontiers in Measurement and Assessment (pp 11-24). New York: Oxford University Press.

Bonar, S.A., Hubert, W.A., \& Willis, D.W. (2009). Standard methods for sampling North American freshwater fishes. Bethesda, Maryland: American Fisheries Society.

Bonar, S.A., Mercado-Silva, N., Hubert, W.A., et al. (2017). Standard methods for sampling freshwater fishes: Opportunities for international collaboration. Fisheries, 42, 150-156. doi: 10.1080/03632415.2017.1276352.

Borchers, D., Buckland, S., \& Zucchini, W. (2002). Estimating animal abundance: closed populations. London, UK: Springer.

Borchers, D.L., Stevenson, B.C., Kidney, D., Thomas, L., \& Marques, T.A. (2015). A unifying model for capture-recapture and distance sampling surveys of wildlife populations. Journal of the American Statistical Association, 110, 195-204. doi: 10.1080/01621459.2014.893884.

Bortolus, A. (2008). Error cascades in the biological sciences: The unwanted consequences of using bad taxonomy in ecology. Ambio, 37, 114-118. doi: 10.1579/00447447(2008)37[114:ECITBS]2.0.CO;2.

Boswell, K.M., Wilson, M.P., \& Wilson, C.A. (2007). Hydroacoustics as a tool for assessing fish biomass and size distribution associated with discrete shallow water estuarine habitats in Louisiana. Estuaries and Coasts, 30, 607-617. doi: 10.1007/BF02841958.

Braithwaite, V. (2010). Do fish feel pain? Oxford, UK: Oxford University Press.

Braun, D.C., \& Reynolds, J.D. (2012). Cost-effective variable selection in habitat surveys. Methods in Ecology and Evolution, 3, 388-396. doi: 10.1111/j.2041-210X.2011.00154.x.

Brenkman, S.J., National Park Service, \& Connolly, P.J. (2008). Protocol for Monitoring Fish Assemblages in Pacific Northwest National Parks. Reston, Virginia, USA.

Britton, J.R., Harper, D.M., \& Oyugi, D.O. (2010). Is the fast growth of an equatorial Micropterus salmoides population explained by high water temperature? Ecology of Freshwater Fish, 19, 228-238. doi: 10.1111/j.1600-0633.2010.00407.x.

Browman, H.I., Cooke, S.J., Cowx, I.G., et al. (2019). Welfare of aquatic animals: where things are, where they are going, and what it means for research, aquaculture, recreational angling, and commercial fishing. ICES Journal of Marine Science, 76, 82-92. doi: 10.1093/icesjms/fsy067.

Buckland, S., Studeny, A., Magurran, A., \& Newson, S. (2011). Biodiversity monitoring: the relevance of detectability. In A. Magurran and B. McGill (Eds) Biological Diversity: Fontiers in Measurement and Assessment (pp 25-36). Oxford: Oxford University Press.

Buckland, S.T., Anderson, D.R., Burnham, K.P., Laake, J.L., Borchers, D.L., \& Thomas, L. (2004). Advanced distance sampling: Estimating abundance of biological populations. Oxford: Oxford University Press.

Buckland, S.T., Anderson, D.R., Burnham, K.P., Laake, J.L., Borchers, D.L., \& Thomas, L. (2001). Introduction to distance sampling: Estimating Abundance of Biological Populations. Oxford: Oxford University Press.

Buckland, S.T., Baillie, S.R., Dick, J.M., et al. (2012). How should regional biodiversity be monitored? Environmental and Ecological Statistics, 19, 601-626. doi: 10.1007/s10651-012-0202-7.

Busst, G.M., \& Britton, J.R. (2014). Precision of the age-length increments of three cyprinids: effects of fish number and sub-sampling strategy. Journal of Fish Biology, 84, 1926-1939. doi: 
$10.1111 /$ jfb. 12409 .

Capra, H., Plichard, L., Bergé, J., Pella, H., Ovidio, M., McNeil, E., \& Lamouroux, N. (2017). Fish habitat selection in a large hydropeaking river: Strong individual and temporal variations revealed by telemetry. Science of The Total Environment, 578, 109-120. doi: 10.1016/j.scitotenv.2016.10.155.

Carpenter, S.R., Frost, T.M., Heisey, D., \& Kratz, T.K. (1989). Randomized intervention analysis and the interpretation of whole-ecoysystem experiments. Ecology, 70, 1142-1152. doi: $10.2307 / 1941382$.

Caughlan, L., \& Oakley, K.L. (2001). Cost considerations for long-term ecological monitoring. Ecological Indicators, 1, 123-134. doi: 10.1016/S1470-160X(01)00015-2.

Cayuela, L., \& Gotelli, N. (2014). rareNMtests: Ecological and biogeographical null model tests for comparing rarefaction curves. https:/cran.r-project.org/package=rareNMtest.

Cayuela, L., Gotelli, N.J., \& Colwell, R.K. (2015). Ecological and biogeographic null hypotheses for comparing rarefaction curves. Ecological Monographs, 85, 437-455. doi: 10.1890/14-1261.1.

CCME (2011). Protocols Manual for Water Quality Sampling in Canada. Winnipeg, Canada: Canadian Council of Ministers of the Environment.

CEN (2003). EN 14011 Water quality - Sampling of fish with electricity. Brussels, Belgium: European Committee for Standardization (CEN).

CEN (2006). EN 14757 Water quality - Sampling of fish with multi-mesh gillnets. Brussels, Belgium: European Committee for Standardization (CEN).

Chao, A., Gotelli, N.J., Hsieh, T.C., Sander, E.L., Ma, K.H., Colwell, R.K., \& Ellison, A.M. (2014). Rarefaction and extrapolation with Hill numbers: a framework for sampling and estimation in species diversity studies. Ecological Monographs, 84, 45-67. doi: 10.1890/13-0133.1.

Charles, A., Garcia, S.M., \& Rice, J. (2016). Balanced harvesting in fisheries: economic considerations. ICES Journal of Marine Science, 73, 1679-1689. doi: 10.1093/icesjms/fsv161.

Chisnall, B.L., \& Kalish, J.M. (1993). Age validation and movement of freshwater eels (Anguilla dieffenbachii and A. australis) in a New Zealand pastoral stream. New Zealand Journal of Marine and Freshwater Research, 27, 333-338. doi: 10.1080/00288330.1993.9516573.

Coding Club (2018). Manipulation and visualisation of spatial and population data. https://ourcodingclub.github.io/2018/01/06/occurrence.html.

Coggins, L.G., Bacheler, N.M., \& Gwinn, D.C. (2014). Occupancy models for monitoring marine fish: A bayesian hierarchical approach to model imperfect detection with a novel gear combination. PLoS ONE, 9, e108302. doi: 10.1371/journal.pone.0108302.

Conroy, M.J., \& Carroll, J.P. (2009). Quantitative Conservation of Vertebrates. Chichester, UK: Wiley-Blackwell.

Cooke, S., Paukert, C., \& Hogan, Z. (2012). Endangered river fish: factors hindering conservation and restoration. Endangered Species Research, 17, 179-191. doi: 10.3354/esr00426.

Cooke, S.J., Arthington, A.A., Bonar, S.A., et al. (2016). Assessment of inland fisheries: A vision for the future. In W.W. Taylor, D.M. Bartley, C.I. Goddard, N.J. Leonard and R. Welcome (Eds) Freshwater, Fish, and the Future: Proceedings of the Global Cross-Sectoral Conference (pp 4562). Rome, Michigan, Bethesda: Food and Agriculture Organization of the United Nations, Michigan State University, American Fisheries Society.

Cooke, S.J., Woodley, C.M., Brad Eppard, M., Brown, R.S., \& Nielsen, J.L. (2011). Advancing the surgical implantation of electronic tags in fish: a gap analysis and research agenda based on a review of trends in intracoelomic tagging effects studies. Reviews in Fish Biology and Fisheries, 21, 127-151. doi: 10.1007/s11160-010-9193-3.

Cooper, M.J., \& Wheatley, G.A. (1981). An examination of the fish population in the River Trent, Nottinghamshire using angler catches. Journal of Fish Biology, 19, 539-556. doi: 10.1111/j.1095-8649.1981.tb03821.x.

Copp, G.H. (2010). Patterns of diel activity and species richness in young and small fishes of European streams: a review of 20 years of point abundance sampling by electrofishing. Fish and Fisheries, 
11, 439-460. doi: 10.1111/j.1467-2979.2010.00370.x.

Costello, M.J., Beard, K.H., Corlett, R.T., et al. (2016). Field work ethics in biological research. Biological Conservation, 203, 268-271. doi: 10.1016/j.biocon.2016.10.008.

Costello, M.J., Michener, W.K., Gahegan, M., Zhang, Z.-Q., \& Bourne, P.E. (2013). Biodiversity data should be published, cited, and peer reviewed. Trends in Ecology \& Evolution, 28, 454-461. doi: 10.1016/j.tree.2013.05.002.

Costello, M.J., \& Wieczorek, J. (2014). Best practice for biodiversity data management and publication. Biological Conservation, 173, 68-73. doi: 10.1016/j.biocon.2013.10.018.

Counihan, T.D., Waite, I.R., Casper, A.F., et al. (2018). Can data from disparate long-term fish monitoring programs be used to increase our understanding of regional and continental trends in large river assemblages? PLoS One, 13, e0191472. doi: 10.1371/journal.pone.0191472.

Cowx, I.G., \& Broughton, N.M. (1986). Changes in the species composition of anglers' catches in the River Trent (England) between 1969 and 1984. Journal of Fish Biology, 28, 625-636. doi: 10.1111/j.1095-8649.1986.tb05197.x.

Cowx, I.G., \& Fraser, D. (2003). Monitoring the Atlantic Salmon Salmo salar. Conserving Natura 2000 Rivers. Monitoring Series No. 7. Peterborough: English Nature.

Cowx, I.G., Harvey, J.P., Noble, R.A., \& Nunn, A.D. (2009). Establishing survey and monitoring protocols for the assessment of conservation status of fish populations in river Special Areas of Conservation in the UK. Aquatic Conservation: Marine and Freshwater Ecosystems, 19, 96-103. doi: 10.1002 aqc. 968 .

Crawford, I.M. (1997). Marketing research and information systems. Rome: Food and Agriculture Organization of the United Nations.

Daan, N. (2001). The IBTS database: a plea for quality control. International Council for the Exploration of the Sea, 3, 1-5.

Darwin, C. (1859). On the origin of species by means of natural selection, or the preservation of favoured races in the struggle for life. London: John Murray.

Davison, P.I., Créach, V., Liang, W.-J., Andreou, D., Britton, J.R., \& Copp, G.H. (2016). Laboratory and field validation of a simple method for detecting four species of non-native freshwater fish using eDNA. Journal of Fish Biology, 89, 1782-1793. doi: 10.1111/jfb.13086.

de Kerckhove, D.T., Minns, C.K., \& Chu, C. (2015). Estimating fish exploitation and aquatic habitat loss across diffuse inland recreational fisheries. PLoS One, 10, e0121895. doi: 10.1371/journal.pone.0121895.

Di Minin, E., Tenkanen, H., \& Toivonen, T. (2015). Prospects and challenges for social media data in conservation science. Frontiers in Environmental Science, 3(63):1-6. doi: 10.3389/fenvs.2015.00063.

Dixon, W., \& Chiswell, B. (1996). Review of aquatic monitoring program design. Water Research, 30, 1935-1948. doi: 10.1016/0043-1354(96)00087-5.

Dornelas, M., Gotelli, N.J., McGill, B., Shimadzu, H., Moyes, F., Sievers, C., \& Magurran, A.E. (2014). Assemblage time series reveal biodiversity change but not systematic loss. Science, 344 , 296-299. doi: 10.1126/science.1248484.

Downes, B.J., Barmuta, L.A., Fairweather, P.G., et al. (2002). Monitoring Ecological Impacts: Concepts and Practice in Flowing Waters. New York: Cambridge University Press.

Dudgeon, D., Arthington, A.H., Gessner, M.O., et al. (2006). Freshwater biodiversity: importance, threats, status and conservation challenges. Biological Reviews, 81, 163-182. doi: 10.1017/S1464793105006950.

Dukerschein, J.T., Bartels, A.D., Ickes, B.S., \& Pearson, M.S. (2011). Are two systemic fish assemblage sampling programmes on the upper Mississippi River telling us the same thing? River Research and Applications, 29, 79-89. doi: 10.1002/rra.1575.

Farnsworth, E.J., \& Rosovsky, J. (1993). The Ethics of Ecological Field Experimentation. Conservation Biology, 7, 463-472. doi: 10.1046/j.1523-1739.1993.07030463.x.

Fausch, K.D., Karr, J.R., \& Yant, P.R. (1984). Regional application of an index of biotic integrity 
based on stream fish communities. Transactions of the American Fisheries Society, 113, 39-55. doi: 10.1577/1548-8659(1984)113<39:RAOAIO $>2.0 . C O ; 2$.

Fausch, K.D.D., Torgersen, C.E.E., Baxter, C.V. V, \& Li, H.W.W. (2002). Landscapes to Riverscapes: Bridging the Gap between Research and Conservation of Stream Fishes. BioScience, 52, 483498. doi: 10.1641/0006-3568(2002)052[0483:LTRBTG]2.0.CO;2.

Fölster, J., Johnson, R.K., Futter, M.N., \& Wilander, A. (2014). The Swedish monitoring of surface waters: 50 years of adaptive monitoring. AMBIO, 43, 3-18. doi: 10.1007/s13280-014-0558-z.

Froese, R., \& Pauly, D. (2018). FishBase. Available at: http://www.fishbase.org.

Frouzova, J., Kubecka, J., Balk, H., \& Frouz, J. (2005). Target strength of some European fish species and its dependence on fish body parameters. Fisheries Research, 75, 86-96. doi: 10.1016/j.fishres.2005.04.011.

Funk, W.C., McKay, J.K., Hohenlohe, P.A., \& Allendorf, F.W. (2012). Harnessing genomics for delineating conservation units. Trends in Ecology \& Evolution, 27, 489-496. doi: 10.1016/j.tree.2012.05.012.

Gallagher, S.P., Wright, D.W., Collins, B.W., \& Adams, P.B. (2010). A Regional Approach for Monitoring Salmonid Status and Trends: Results from a Pilot Study in Coastal Mendocino County, California. North American Journal of Fisheries Management, 30, 1075-1085. doi: 10.1577/M09-203.1.

Gotelli, N., \& Colwell, R. (2011). Estimating species richness. In A. Magurran and B. McGill (Eds) Biological Diversity: Frontiers in Measurement and Assessment (pp 39-54). Oxford: Oxford University Press.

Gotelli, N.J., \& Colwell, R.K. (2001). Quantifying biodiversity: procedures and pitfalls in the measurement and comparison of species richness. Ecology Letters, 4, 379-391. doi: 10.1046/j.1461-0248.2001.00230.x.

Graham, C.T., \& Harrod, C. (2009). Implications of climate change for the fishes of the British Isles. Journal of Fish Biology, 74, 1143-1205. doi: 10.1111/j.1095-8649.2009.02180.x.

Guillard, J., \& Vergès, C. (2007). The repeatability of fish biomass and size distribution estimates obtained by hydroacoustic surveys using various sampling strategies and statistical analyses. International Review of Hydrobiology, 92, 605-617. doi: 10.1002/iroh.200710948.

Gutmann Roberts, C., Bašić, T., Amat Trigo, F., \& Britton, J.R. (2017). Trophic consequences for riverine cyprinid fishes of angler subsidies based on marine-derived nutrients. Freshwater Biology, 62, 894-905. doi: 10.1111/fwb.12910.

Hamel, M.J., Pegg, M.A., Goforth, R.R., Phelps, Q.E., Steffensen, K.D., Hammen, J.J., \& Rugg, M.L. (2015). Range-wide age and growth characteristics of shovelnose sturgeon from mark-recapture data: implications for conservation and management. Canadian Journal of Fisheries and Aquatic Sciences, 72, 71-82. doi: 10.1139/cjfas-2014-0238.

Hamidan, N., \& Britton, J.R. (2015). Age and growth rates of the critically endangered fish Garra ghorensis can inform their conservation management. Aquatic Conservation: Marine and Freshwater Ecosystems, 25, 61-70. doi: 10.1002/aqc.2449.

Hänfling, B., Bolton, P., Harley, M., \& Carvalho, G.R. (2005). A molecular approach to detect hybridisation between crucian carp (Carassius carassius) and non-indigenous carp species (Carassius spp. and Cyprinus carpio). Freshwater Biology, 50, 403-417. doi: 10.1111/j.13652427.2004.01330.x.

Hänfling, B., Lawson Handley, L., Read, D.S., et al. (2016). Environmental DNA metabarcoding of lake fish communities reflects long-term data from established survey methods. Molecular Ecology, 25, 3101-3119. doi: 10.1111/mec.13660.

Harby, A., Olivier, J.-M., Merigoux, S., \& Malet, E. (2007). A mesohabitat method used to assess minimum flow changes and impacts on the invertebrate and fish fauna in the Rhône River, France. River Research and Applications, 23, 525-543. doi: 10.1002/rra.997.

Hargrove, W.W., \& Pickering, J. (1992). Pseudoreplication: a sine qua non for regional ecology. Landscape Ecology, 6, 251-258. doi: 10.1007/BF00129703. 
Harris, D.J. (2003). Can you bank on GenBank? Trends in Ecology \& Evolution, 18, 317-319. doi: 10.1016/S0169-5347(03)00150-2.

Haxton, T. (2011). Depth selectivity and spatial distribution of juvenile lake sturgeon in a large, fragmented river. Journal of Applied Ichthyology, 27, 45-52. doi: 10.1111/j.14390426.2011.01872.x.

Hellawell, J.M. (1991). Development of a rationale for monitoring. In B. Goldsmith (Ed) Monitoring for Conservation and Ecology (pp 1-14). London: Chapman \& Hall.

Hinds, W.T. (1984). Towards monitoring of long-term trends in terrestrial ecosystems. Environmental Conservation, 11, 11-18. doi: 10.1017/S0376892900013448.

Hobbs, N.T., \& Hooten, M.B. (2015). Bayesian models: a statistical primer for ecologists. Princeton (US) \& Woodstock (UK): Princeton University Press.

Holmgren, K., Degerman, E., Petersson, E., \& Bergquist, B. (2016). Long term trends of fish after liming of Swedish streams and lakes. Atmospheric Environment, 146, 245-251. doi: 10.1016/j.atmosenv.2016.08.033.

Holmlund, C.M., \& Hammer, M. (1999). Ecosystem services generated by fish populations. Ecological Economics, 29, 253-268. doi: 10.1016/S0921-8009(99)00015-4.

Hsieh, T.C., Ma, K.H., \& Chao, A. (2016). iNEXT: an R package for rarefaction and extrapolation of species diversity (Hill numbers). Methods in Ecology and Evolution, 7, 1451-1456. doi: 10.1111/2041-210X.12613.

Huey, J.A., Schmidt, D.J., Balcombe, S.R., Marshall, J.C., \& Hughes, J.M. (2011). High gene flow and metapopulation dynamics detected for three species in a dryland river system. Freshwater Biology, 56, 2378-2390. doi: 10.1111/j.1365-2427.2011.02666.x.

Hughes, S. (1998). A mobile horizontal hydroacoustic fisheries survey of the River Thames, United Kingdom. Fisheries Research, 35, 91-97. doi: 10.1016/S0165-7836(98)00063-0.

Huntingford, F., Adams, C., Braithwaite, V.A., Kadri, S., Pottinger, T.G., Sandoe, P., \& Turnbull, J.F. (2007). The implications of a feelings-based approach to fish welfare: a reply to Arlinghaus et al. Fish and Fisheries, 8, 277-280. doi: 10.1111/j.1467-2679.2007.00254.x.

Huntingford, F.A., Adams, C., Braithwaite, V.A., Kadri, S., Pottinger, T.G., Sandoe, P., \& Turnbull, J.F. (2006). Current issues in fish welfare. Journal of Fish Biology, 68, 332-372. doi: 10.1111/j.0022-1112.2006.001046.x.

Hurford, C. (2010). Conservation monitoring in freshwater habitats: an introduction. In C. Hurford, M. Schneider and I. Cowx (Eds) Conservation Monitoring in Freshwater Habitats (pp 3-13). Dordrecht: Springer.

Iknayan, K.J., Tingley, M.W., Furnas, B.J., \& Beissinger, S.R. (2014). Detecting diversity: emerging methods to estimate species diversity. Trends in Ecology \& Evolution, 29, 97-106. doi: 10.1016/j.tree.2013.10.012.

Isaak, D.J., Ver Hoef, J.M., Peterson, E.E., Horan, D.L., \& Nagel, D.E. (2017). Scalable population estimates using spatial-stream-network (SSN) models, fish density surveys, and national geospatial database frameworks for streams. Canadian Journal of Fisheries and Aquatic Sciences, 74, 147-156. doi: 10.1139/cjfas-2016-0247.

Isaak, D.J., Peterson, E.E., Ver Hoef, J.M., et al. (2014). Applications of spatial statistical network models to stream data. WIREs Water, 1, 277-294. doi: 10.1002/wat2.1023.

IUCN FFSG (2015). Importance of freshwater fishes. Available at: http://www.iucnffsg.org/freshwater-fishes/importance-of-freshwater-fishes/.

Jerde, C.L., Mahon, A.R., Chadderton, W.L., \& Lodge, D.M. (2011). "Sight-unseen” detection of rare aquatic species using environmental DNA. Conservation Letters, 4, 150-157. doi: 10.1111/j.1755-263X.2010.00158.x.

Jones, C.M., Robson, D.S., Lakkis, H.D., \& Kressel, J. (1995). Properties of catch rates used in analysis of angler surveys. Transactions of the American Fisheries Society, 124, 911-928. doi: 10.1577/1548-8659(1995)124<0911:POCRUI>2.3.CO;2.

Joy, M., David, B., \& Lake, M. (2013). New Zealand freshwater fish sampling protocols - Wadeable 
rivers and streams. Palmerston North: Massey University, The Ecology Group - Institute of Natural Resources.

Kershner, J.L. (1997). Monitoring and adaptive management. In J.E. Williams, C.A. Wood and M.P. Dombeck (Eds) Watershed Restoration: Principles and Practices (pp 116-131). Bethesda: American Fisheries Society.

Kincaid, T.M., \& Olsen, A.R. (2016). spsurvey: Spatial Survey Design and Analysis. https://cran.rproject.org/package $=$ spsurvey.

Knebelsberger, T., Dunz, A.R., Neumann, D., \& Geiger, M.F. (2015). Molecular diversity of Germany's freshwater fishes and lampreys assessed by DNA barcoding. Molecular Ecology Resources, 15, 562-572. doi: 10.1111/1755-0998.12322.

Lacoursière-Roussel, A., Côté, G., Leclerc, V., \& Bernatchez, L. (2016). Quantifying relative fish abundance with eDNA: a promising tool for fisheries management. Journal of Applied Ecology, 53, 1148-1157. doi: 10.1111/1365-2664.12598.

Laffaille, P., Briand, C., Fatin, D., Lafage, D., \& Lasne, E. (2005). Point sampling the abundance of European eel (Anguilla anguilla) in freshwater areas. Archiv für Hydrobiologie, 162, 91-98. doi: 10.1127/0003-9136/2005/0162-0091.

Langangen, Ø., Edeline, E., Ohlberger, J., et al. (2011). Six decades of pike and perch population dynamics in Windermere. Fisheries Research, 109, 131-139. doi: 10.1016/j.fishres.2011.01.029.

Lara, A., Ponce de León, J.L., Rodríguez, R., Casane, D., Côté, G., Bernatchez, L., \& García-Machado, E. (2010). DNA barcoding of Cuban freshwater fishes: Evidence for cryptic species and taxonomic conflicts. Molecular Ecology Resources, 10, 421-430. doi: 10.1111/j.17550998.2009.02785.x.

Larsen, D.P., Kincaid, T.M., Jacobs, S.E., \& Urquhart, N.S. (2001). Designs for evaluating local and regional scale trends. BioScience, 51, 1069-1078. doi: 10.1641/00063568(2001)051[1069:DFELAR]2.0.CO;2.

Larsen, D.P., Olsen, A.R., \& Stevens, D.L. (2008). Using a Master Sample to Integrate Stream Monitoring Programs. Journal of Agricultural, Biological, and Environmental Statistics, 13, 243-254. doi: 10.1198/108571108X336593.

Lawson Handley, L. (2015). How will the 'molecular revolution' contribute to biological recording? Biological Journal of the Linnean Society, 115, 750-766. doi: 10.1111/bij.12516.

Legg, C.J., \& Nagy, L. (2006). Why most conservation monitoring is, but need not be, a waste of time. Journal of Environmental Management, 78, 194-199. doi: 10.1016/j.jenvman.2005.04.016.

Letcher, B.H., Schueller, P., Bassar, R.D., et al. (2015). Robust estimates of environmental effects on population vital rates: an integrated capture-recapture model of seasonal brook trout growth, survival and movement in a stream network. Journal of Animal Ecology, 84, 337-352. doi: 10.1111/1365-2656.12308.

Lévêque, C., Oberdorff, T., Paugy, D., Stiassny, M.L.J., \& Tedesco, P.A. (2008). Global diversity of fish (Pisces) in freshwater. Hydrobiologia, 595, 545-567. doi: 10.1007/s10750-007-9034-0.

Lin, H.-Y., Brown, C.J., Dwyer, R.G., et al. (2018). Impacts of fishing, river flow and connectivity loss on the conservation of a migratory fish population. Aquatic Conservation: Marine and Freshwater Ecosystems, 28, 45-54. doi: 10.1002/aqc.2831.

Lindenmayer, D.B., \& Likens, G.E. (2009). Adaptive monitoring: a new paradigm for long-term research and monitoring. Trends in Ecology \& Evolution, 24, 482-486. doi: 10.1016/j.tree.2009.03.005.

Lindenmayer, D.B., \& Likens, G.E. (2010). The science and application of ecological monitoring. Biological Conservation, 143, 1317-1328. doi: 10.1016/j.biocon.2010.02.013.

Lindenmayer, D.B., Likens, G.E., Haywood, A., \& Miezis, L. (2011). Adaptive monitoring in the real world: proof of concept. Trends in Ecology \& Evolution, 26, 641-646. doi: 10.1016/j.tree.2011.08.002.

Lohammar, G. (1938). Wasserchemie und höhere Vegetation schwedischer Seen. Symbolae Botanicae Upsaliensis, III, 1-252. 
Lovett, G.M., Burns, D.A., Driscoll, C.T., et al. (2007). Who needs environmental monitoring? Frontiers in Ecology and the Environment, 5, 253-260. doi: 10.1890/15409295(2007)5[253:WNEM]2.0.CO;2.

Lowe, W., Likens, G.E., \& Power, M.E. (2006). Linking scales in stream ecology. BioScience, 56, 591-597. doi: 10.1641/0006-3568(2006)56[591:LSISE]2.0.CO;2.

Lucas, M.C., \& Baras, E. (2000). Methods for studying spatial behaviour of freshwater fishes in the natural environment. Fish and Fisheries, 1, 283-316. doi: 10.1046/j.1467-2979.2000.00028.x.

Lucas, M.C., \& Batley, E. (1996). Seasonal movements and behaviour of adult barbel Barbus barbus, a riverine cyprinid fish: implications for river management. Journal of Applied Ecology, 33, 13451358. doi: 10.2307/2404775.

Lundqvist, H., Leonardsson, K., Carlsson, U., et al. (2010). Monitoring Juvenile Atlantic Salmon and Sea Trout in the River Sävarån, Northern Sweden. In C. Hurford, M. Schneider and I.G. Cowx (Eds) Conservation Monitoring in Freshwater Habitats (pp 207-218). Dordrecht, Heidelberg, London, New York: Springer Science \& Business Media.

Lyons, J. (1998). A hydroacoustic assessment of fish stocks in the River Trent, England. Fisheries Research, 35, 83-90. doi: 10.1016/S0165-7836(98)00062-9.

MacArthur, R.H., \& Wilson, E.O. (1967). The Theory of Island Biogeography. New Jersey: Princeton University Press.

MacKenzie, D., Nichols, J., Royle, J., Pollock, K., Bailey, L., \& Hines, J. (2006). Occupancy estimation and modeling: inferring patterns and dynamics of species occurrence. San Diego: Academic Press.

MacKenzie, D.I., Nichols, J.D., Lachman, G.B., Droege, S., Royle, A.A., \& Langtimm, C.A. (2002). Estimating site occupancy rates when detection probabilities are less than one. Ecology, 83, 2248-2255. doi: 10.1890/0012-9658(2002)083[2248:ESORWD]2.0.CO;2.

Magurran, A.E. (2004). Measuring Biological Diversity. Oxford: Blackwell Science Ltd.

Magurran, A.E. (2011). Measuring biological diversity in time (and space). In A. Magurran and B. McGill (Eds) Biological diversity: frontiers in measurement and assessment (pp 85-94). Oxford: Oxford University Press.

Magurran, A.E., Deacon, A.E., Moyes, F., Shimadzu, H., Dornelas, M., Phillip, D.A.T., \& Ramnarine, I.W. (2018). Divergent biodiversity change within ecosystems. Proceedings of the National Academy of Sciences, 115, 1843-1847. doi: 10.1073/pnas.1712594115.

Magurran, A.E., \& McGill, B.J. (2011). Biological diversity: Frontiers in Measurement and Assessment. Oxford: Oxford University Press.

Marsh, D.M., \& Trenham, P.C. (2008). Current trends in plant and animal population monitoring. Conservation Biology, 22, 647-655. doi: 10.1111/j.1523-1739.2008.00927.x.

Maxwell, D., \& Jennings, S. (2005). Power of monitoring programmes to detect decline and recovery of rare and vulnerable fish. Journal of Applied Ecology, 42, 25-37. doi: 10.1111/j.13652664.2005.01000.x.

Michener, W.K. (2006). Meta-information concepts for ecological data management. Ecological Informatics, 1, 3-7. doi: 10.1016/j.ecoinf.2005.08.004.

Michener, W.K. (2015). Ten simple rules for creating a good data management plan. PLOS Computational Biology, 11, e1004525. doi: 10.1371/journal.pcbi.1004525.

Michener, W.K., \& Brunt, J.W. (2000). Ecological data: design, management, and processing. Oxford: Blackwell Science.

Michener, W.K., \& Jones, M.B. (2012). Ecoinformatics: supporting ecology as a data-intensive science. Trends in Ecology \& Evolution, 27, 85-93. doi: 10.1016/j.tree.2011.11.016.

Mihoub, J.-B., Henle, K., Titeux, N., Brotons, L., Brummitt, N.A., \& Schmeller, D.S. (2017). Setting temporal baselines for biodiversity: the limits of available monitoring data for capturing the full impact of anthropogenic pressures. Scientific Reports, 7, 41591. doi: 10.1038/srep41591.

Milner, N., Wyatt, R., \& Broad, K. (1998). HABSCORE - applications and future developments of related habitat models. Aquatic Conservation: Marine and Freshwater Ecosystems, 8, 633-644. 
doi: 10.1002/(SICI)1099-0755(199807/08)8:4<633::AID-AQC275>3.0.CO;2-7.

Minteer, B.A., Collins, J.P., Love, K.E., \& Puschendorf, R. (2014). Avoiding (Re)extinction. Science, 344, 260-261. doi: 10.1126/science.1250953.

Moe, S.J., Schmidt-Kloiber, A., Dudley, B.J., \& Hering, D. (2013). The WISER way of organising ecological data from European rivers, lakes, transitional and coastal waters. Hydrobiologia, 704, 11-28. doi: 10.1007/s10750-012-1337-0.

Nichols, J., \& Williams, B. (2006). Monitoring for conservation. Trends in Ecology \& Evolution, 21, 668-673. doi: 10.1016/j.tree.2006.08.007.

Noble, R.A.A., Cowx, I.G., Goffaux, D., \& Kestemont, P. (2007). Assessing the health of European rivers using functional ecological guilds of fish communities: Standardising species classification and approaches to metric selection. Fisheries Management and Ecology, 14, 381-392. doi: 10.1111/j.1365-2400.2007.00575.x.

Ormerod, S.J., Dobson, M., Hildrew, A.G., \& Townsend, C.R. (2010). Multiple stressors in freshwater ecosystems. Freshwater Biology, 55, 1-4. doi: 10.1111/j.1365-2427.2009.02395.x.

Osenberg, C., Bolker, B., White, J., St. Mary, C., \& Shima, J. (2006). Statistical issues and study design in ecological restorations: lessons learned from marine reserves. In D.A. Falk, M.A. Palmer and J.B. Zedler (Eds) Foundations of Restoration Ecology (pp 280-302). Washington, Covelo, London: Island Press.

Peterman, R.M. (1990). Statistical power analysis can improve fisheries research and management. Canadian Journal of Fisheries and Aquatic Sciences, 47, 2-15. doi: 10.1139/f90-001.

Peterson, E.E., \& Ver Hoef, J.M. (2014). STARS: An ArcGIS toolset used to calculate the spatial information needed to fit spatial statistical models to stream network data. Journal of Statistical Software, 56, 1-17. doi: 10.18637/jss.v056.i02.

Peterson, M.J., Mathews, T.J., Ryon, M.G., et al. (2013). Y-12 National Security Complex Biological Monitoring and Abatement Program Plan. Oak Ridge, TN, USA: U.S. Department of Energy.

Pielou, E. (1975). Ecological diversity. New York: Wiley Interscience.

Pinder, A., Raghavan, R., \& Britton, J. (2015a). The legendary hump-backed mahseer Tor sp. of India's River Cauvery: an endemic fish swimming towards extinction? Endangered Species Research, 28, 11-17. doi: 10.3354/esr00673.

Pinder, A.C., Raghavan, R., \& Britton, J.R. (2015b). Efficacy of angler catch data as a population and conservation monitoring tool for the flagship Mahseer fishes (Tor spp.) of Southern India. Aquatic Conservation: Marine and Freshwater Ecosystems, 25, 829-838. doi: 10.1002/aqc.2543.

Poizat, G., \& Baran, E. (1997). Fishermen's knowledge as background information in tropical fish ecology: A quantitative comparison with fish sampling results. Environmental Biology of Fishes, 50, 435-449. doi: 10.1023/A:1007317423165.

Polasky, S., Carpenter, S.R., Folke, C., \& Keeler, B. (2011). Decision-making under great uncertainty: environmental management in an era of global change. Trends in Ecology \& Evolution, 26, 398404. doi: 10.1016/j.tree.2011.04.007.

Pollock, K.H., Nichols, J.D., Simons, T.R., Farnsworth, G.L., Bailey, L.L., \& Sauer, J.R. (2002). Large scale wildlife monitoring studies: statistical methods for design and analysis. Environmetrics, 13, 105-119. doi: 10.1002/env.514.

Pont, D., Hugueny, B., \& Rogers, C. (2007). Development of a fish-based index for the assessment of river health in Europe: The European Fish Index. Fisheries Management and Ecology, 14, 427439. doi: 10.1111/j.1365-2400.2007.00577.x.

Pope, K.L., Lochmann, S.E., \& Young, M.K. (2010). Methods for assessing fish populations. In W.A. Hubert and M.C. Quist (Eds) Inland fisheries management in North America (pp 325-351). Bethesda, MD: American Fisheries Society.

Quinn, G.P., \& Keough, M.J. (2002). Experimental Design and Data Analysis for Biologists. Cambridge: Cambridge University Press.

R Core Team (2017). R: A Language and Environment for Statistical Computing. Vienna, Austria: R Foundation for Statistical Computing, http://www.r-project.org/. 
Radinger, J., Hölker, F., Horký, P., Slavík, O., Dendoncker, N., \& Wolter, C. (2016). Synergistic and antagonistic interactions of future land use and climate change on river fish assemblages. Global Change Biology, 22, 1505-1522. doi: 10.1111/gcb.13183.

Radinger, J., \& Wolter, C. (2014). Patterns and predictors of fish dispersal in rivers. Fish and Fisheries, 15, 456-473. doi: 10.1111/faf.12028.

Reichman, O.J., Jones, M.B., \& Schildhauer, M.P. (2011). Challenges and opportunities of open data in ecology. Science, 331, 692-693. doi: 10.1126/science.1197962.

Revenga, C., Campbell, I., Abell, R., de Villiers, P., \& Bryer, M. (2005). Prospects for monitoring freshwater ecosystems towards the 2010 targets. Philosophical Transactions of the Royal Society B: Biological Sciences, 360, 397-413. doi: 10.1098/rstb.2004.1595.

Rocha, L.A., Aleixo, A., Allen, G., et al. (2014). Specimen collection: An essential tool. Science, 344, 814-815. doi: 10.1126/science.344.6186.814.

Rose, J.D., Arlinghaus, R., Cooke, S.J., Diggles, B.K., Sawynok, W., Stevens, E.D., \& Wynne, C.D.L. (2014). Can fish really feel pain? Fish and Fisheries, 15, 97-133. doi: 10.1111/faf.12010.

Roussel, J.-M., Paillisson, J.-M., Tréguier, A., \& Petit, E. (2015). The downside of eDNA as a survey tool in water bodies. Journal of Applied Ecology, 52, 823-826. doi: 10.1111/1365-2664.12428.

Royle, J.A., \& Link, W.A. (2006). Generalized site occupancy models allowing for false positive and false negative errors. Ecology, 87, 835-841. doi: 10.1890/00129658(2006)87[835:GSOMAF]2.0.CO;2.

Rüegg, J., Gries, C., Bond-Lamberty, B., et al. (2014). Completing the data life cycle: using information management in macrosystems ecology research. Frontiers in Ecology and the Environment, 12, 24-30. doi: 10.1890/120375.

Sala, O.E., Chapin III, F.S., Armesto, J.J., et al. (2000). Global biodiversity scenarios for the year 2100. Science, 287, 1770-1775. doi: 10.1126/science.287.5459.1770.

Sandlund, O.T., Museth, J., \& Øistad, S. (2016). Migration, growth patterns, and diet of pike (Esox lucius) in a river reservoir and its inflowing river. Fisheries Research, 173, 53-60. doi: 10.1016/j.fishres.2015.08.010.

Santhanam, R. (2015). Nutritional freshwater life. Boca Raton, Florida: CRC Press, Taylor \& Francis Group.

Santos, A.M., \& Branco, M. (2012). The quality of name-based species records in databases. Trends in Ecology \& Evolution, 27, 6-7. doi: 10.1016/j.tree.2011.10.004.

Sass, G.G., Cook, T.R., Irons, K.S., McClelland, M.A., Michaels, N.N., Matthew O’Hara, T., \& Stroub, M.R. (2010). A mark-recapture population estimate for invasive silver carp (Hypophthalmichthys molitrix) in the La Grange Reach, Illinois River. Biological Invasions, 12, 433-436. doi: 10.1007/s10530-009-9462-z.

Schiemer, F. (2000). Fish as indicators for the assessment of the ecological integrity of large rivers. Hydrobiologia , 422/423, 271-278. doi: 10.1023/A:1017086703551.

Schindler, D.W. (1998). Whole-ecosystem experiments: replication versus realism: The need for ecosystem-scale experiments. Ecosystems, 1, 323-334. doi: 10.1007/s100219900026.

Schmutz, S., Kaufmann, M., Vogel, B., Jungwirth, M., \& Muhar, S. (2000). A multi-level concept for fish-based, river-type-specific assessment of ecological integrity. Hydrobiologia, 422/423, 279289. doi: 10.1023/A:1017038820390.

Serrao, N.R., Steinke, D., \& Hanner, R.H. (2014). Calibrating snakehead diversity with DNA barcodes: Expanding taxonomic coverage to enable identification of potential and established invasive species. PLoS ONE, 9, e99546. doi: 10.1371/journal.pone.0099546.

Simon, T.P., \& Evans, N.T. (2017). Environmental Quality Assessment Using Stream Fishes. In G.A. Lamberti and F.R. Hauer (Eds) Methods in Stream Ecology. Volume 2: Ecosystem Function. (pp 319-334). London: Elsevier.

Sloman, K.A., Bouyoucos, I.A., Brooks, E.J., \& Sneddon, L.U. (2019). Ethical considerations in fish research. Journal of Fish Biology, 94, 556-577. doi: 10.1111/jfb.13946.

Snyder, D.E. (2003). Invited overview: conclusions from a review of electrofishing and its harmful 
effects on fish. Reviews in Fish Biology and Fisheries, 13, 445-453. doi: 10.1007/s11160-0041095-9.

Southwood, T., \& Henderson, P. (2000). Ecological methods. Oxford: Blackwell Science.

Steidl, R.J., Hayes, J.P., \& Schauber, E. (1997). Statistical power analysis in wildlife research. The Journal of Wildlife Management, 61, 270-279. doi: 10.2307/3802582.

Stendera, S., Adrian, R., Bonada, N., et al. (2012). Drivers and stressors of freshwater biodiversity patterns across different ecosystems and scales: A review. Hydrobiologia, 696, 1-28. doi: 10.1007/s10750-012-1183-0.

Stevens, D.L., \& Olsen, A.R. (2004). Spatially balanced sampling of natural resources. Journal of the American Statistical Association, 99, 262-278. doi: 10.1198/016214504000000250.

Stevens, D.L., \& Olsen, A.R. (2003). Variance estimation for spatially balanced samples of environmental resources. Environmetrics, 14, 593-610. doi: 10.1002/env.606.

Stevens, D.L., \& Urquhart, N.S. (2000). Response designs and support regions in sampling continuous domains. Environmetrics, 11, 13-41. doi: 10.1002/(SICI)1099-095X(200001/02)11:1<13::AIDENV379>3.0.CO;2-8.

Stewart-Oaten, A., \& Bence, J.R. (2001). Temporal and spatial variation in environmental impact assessment. Ecological Monographs, 71, 305-339. doi: 10.1890/00129615(2001)071[0305:TASVIE]2.0.CO;2.

Strayer, D.L., \& Dudgeon, D. (2010). Freshwater biodiversity conservation: recent progress and future challenges. Journal of the North American Benthological Society, 29, 344-358. doi: 10.1899/08171.1 .

Stribling, J.B., Moulton, S.R., \& Lester, G.T. (2003). Determining the quality of taxonomic data. Journal of the North American Benthological Society, 22, 621-631. doi: 10.2307/1468357.

Stribling, J.B., Pavlik, K.L., Holdsworth, S.M., \& Leppo, E.W. (2008). Data quality, performance, and uncertainty in taxonomic identification for biological assessments. Journal of the North American Benthological Society, 27, 906-919. doi: 10.1899/07-175.1.

Strobl, R.O., \& Robillard, P.D. (2008). Network design for water quality monitoring of surface freshwaters: A review. Journal of Environmental Management, 87, 639-648. doi: 10.1016/j.jenvman.2007.03.001.

Sutter, R.D., Wainscott, S.B., Boetsch, J.R., Palmer, C.J., \& Rugg, D.J. (2015). Practical guidance for integrating data management into long-term ecological monitoring projects. Wildlife Society Bulletin, 39, 451-463. doi: 10.1002/wsb.548.

Takahara, T., Minamoto, T., Yamanaka, H., Doi, H., \& Kawabata, Z. (2012). Estimation of fish biomass using environmental DNA. PLoS ONE, 7, e35868. doi: 10.1371/journal.pone.0035868.

Thiault, L., Kernaléguen, L., Osenberg, C.W., \& Claudet, J. (2017). Progressive-Change BACIPS: a flexible approach for environmental impact assessment. Methods in Ecology and Evolution, 8, 288-296. doi: 10.1111/2041-210X.12655.

Thiem, J.D., Taylor, M.K., McConnachie, S.H., Binder, T.R., \& Cooke, S.J. (2011). Trends in the reporting of tagging procedures for fish telemetry studies that have used surgical implantation of transmitters: a call for more complete reporting. Reviews in Fish Biology and Fisheries, 21, 117126. doi: 10.1007/s11160-010-9194-2.

Thomas, L. (1996). Monitoring long-term population change: Why are there so many analysis methods? Ecology, 77, 49-58. doi: 10.2307/2265653.

Thomsen, P.F., Kielgast, J., Iversen, L.L., et al. (2012). Monitoring endangered freshwater biodiversity using environmental DNA. Molecular Ecology, 21, 2565-2573. doi: 10.1111/j.1365294X.2011.05418.x.

Thorp, J.H., Thoms, M.C., \& Delong, M.D. (2006). The riverine ecosystem synthesis: Biocomplexity in river networks across space and time. River Research and Applications, 22, 123-147. doi: 10.1002/rra.901.

Troudet, J., Grandcolas, P., Blin, A., Vignes-Lebbe, R., \& Legendre, F. (2017). Taxonomic bias in biodiversity data and societal preferences. Scientific Reports, 7, 9132. doi: 10.1038/s41598-017- 
09084-6.

Turner, C.R., Uy, K.L., \& Everhart, R.C. (2015). Fish environmental DNA is more concentrated in aquatic sediments than surface water. Biological Conservation, 183, 93-102. doi: 10.1016/j.biocon.2014.11.017.

Turner, M.G., Gardner, R.H., \& O’Neill, R.V. (2001). Landscape Ecology in Theory and Practice. New York: Springer.

Valbo-Jørgensen, J., \& Poulsen, A.F. (2000). Using local knowledge as a research tool in the study of river fish biology: Experiences from the Mekong. Environment, Developement and Sustainability, 2, 253-376. doi: 10.1023/A:1011418225338.

Van Liefferinge, C., Simoens, I., Vogt, C., et al. (2010). Impact of habitat diversity on the sampling effort required for the assessment of river fish communities and IBI. Hydrobiologia, 644, 169183. doi: 10.1007/s10750-010-0110-5.

Venturelli, P.A., Hyder, K., \& Skov, C. (2017). Angler apps as a source of recreational fisheries data: opportunities, challenges and proposed standards. Fish and Fisheries, 18, 578-595. doi: 10.1111/faf.12189.

Ver Hoef, J.M., Peterson, E.E., Clifford, D., \& Shah, R. (2014). SSN: An R package for spatial statistical modeling on stream networks. Journal of Statistical Software, 56, 1-45. doi: 10.18637/jss.v056.i03.

Vidal, O., García-Berthou, E., Tedesco, P.A., \& García-Marín, J.-L. (2010). Origin and genetic diversity of mosquitofish (Gambusia holbrooki) introduced to Europe. Biological Invasions, 12, 841-851. doi: 10.1007/s10530-009-9505-5.

Vindenes, Y., Edeline, E., Ohlberger, J., Langangen, Ø., Winfield, I.J., Stenseth, N.C., \& Vøllestad, L.A. (2014). Effects of climate change on trait-based dynamics of a top predator in freshwater ecosystems. The American Naturalist, 183, 243-256. doi: 10.1086/674610.

Vines, T.H., Albert, A.Y.K., Andrew, R.L., et al. (2014). The availability of research data declines rapidly with article age. Current Biology, 24, 94-97. doi: 10.1016/j.cub.2013.11.014.

Vink, C.J., Paquin, P., \& Cruickshank, R.H. (2012). Taxonomy and irreproducible biological science. BioScience, 62, 451-452. doi: 10.1525/bio.2012.62.5.3.

Vörösmarty, C.J., McIntyre, P.B., Gessner, M.O., et al. (2010). Global threats to human water security and river biodiversity. Nature, 467, 555-561. doi: 10.1038/nature09440.

Wägele, H., Klussmann-Kolb, A., Kuhlmann, M., Haszprunar, G., Lindberg, D., Koch, A., \& Wägele, J.W. (2011). The taxonomist - an endangered race. A practical proposal for its survival. Frontiers in Zoology, 8, 25. doi: 10.1186/1742-9994-8-25.

Wagner, T., Deweber, J.T., Detar, J., Kristine, D., \& Sweka, J.A. (2014). Spatial and temporal dynamics in brook trout density: Implications for population monitoring. North American Journal of Fisheries Management, 34, 258-269. doi: 10.1080/02755947.2013.847878.

Wenger, S.J., \& Freeman, M.C. (2008). Estimating species occurrence, abundance, and detection probability using zero-inflated distributions. Ecology, 89, 2953-2959. doi: 10.1890/07-1127.1.

Wenger, S.J., Leasure, D.R., Dauwalter, D.C., Peacock, M.M., Dunham, J.B., Chelgren, N.D., \& Neville, H.M. (2017). Viability analysis for multiple populations. Biological Conservation, 216, 69-77. doi: 10.1016/j.biocon.2017.10.006.

Wheeler, K., Wenger, S.J., Walsh, S.J., Martin, Z.P., Jelks, H.L., \& Freeman, M.C. (2018). Stream fish colonization but not persistence varies regionally across a large North American river basin. Biological Conservation, 223, 1-10. doi: 10.1016/j.biocon.2018.04.023.

Wilde, G.R., \& Fisher, W.L. (1996). Reservoir fisheries sampling and experimental design. In L.E. Miranda and D.R. DeVries (Eds) Multidimensional Approaches to Reservoir Fisheries Management, Vol. 16 (pp 397-407). Bethesda, Maryland: American Fisheries Society.

Winfield, I.J., Fletcher, J.M., \& James, J. Ben (2012). Long-term changes in the diet of pike (Esox lucius), the top aquatic predator in a changing Windermere. Freshwater Biology, 57, 373-383. doi: $10.1111 / \mathrm{j} .1365-2427.2011 .02607 . x$.

Winfield, I.J., Fletcher, J.M., \& James, J.B. (2010). An overview of fish species introductions to the 
English Lake District, UK, an area of outstanding conservation and fisheries importance. Journal of Applied Ichthyology, 26, 60-65. doi: 10.1111/j.1439-0426.2010.01504.x.

Winfield, I.J., Fletcher, J.M., \& James, J.B. (2008). The Arctic charr (Salvelinus alpinus) populations of Windermere, UK: population trends associated with eutrophication, climate change and increased abundance of roach (Rutilus rutilus). Environmental Biology of Fishes, 83, 25-35. doi: 10.1007/s10641-007-9235-4.

Wolter, C. (2015). Historic catches, abundance, and decline of Atlantic salmon Salmo salar in the River Elbe. Aquatic Sciences, 77, 367-380. doi: 10.1007/s00027-014-0372-5.

Young, M.K., McKelvey, K.S., Pilgrim, K.L., \& Schwartz, M.K. (2013). DNA barcoding at riverscape scales: assessing biodiversity among fishes of the genus Cottus (Teleostei) in northern Rocky Mountain streams. Molecular Ecology Resources, 13, 583-595. doi: 10.1111/1755-0998.12091.

Zale, A. V., Parrish, D.L., Sutton, T.M., \& American Fisheries Society. (2012). Fisheries techniques. Bethesda, Maryland: American Fisheries Society.

Zhang, H., Wei, Q.W., Du, H., Shen, L., Li, Y.H., \& Zhao, Y. (2009). Is there evidence that the Chinese paddlefish (Psephurus gladius) still survives in the upper Yangtze River? Concerns inferred from hydroacoustic and capture surveys, 2006-2008. Journal of Applied Ichthyology, 25, 95-99. doi: $10.1111 /$ j.1439-0426.2009.01268.x. 